\title{
OECD MCCI Project \\ Small-Scale Water Ingression and Crust Strength Tests (SSWICS) Design Report
}

Rev. 2 October 31, 2002

by:

M. Farmer, S. Lomperski, D. Kilsdonk, B. Aeschlimann, P. Pfeiffer

\author{
Reactor Analysis and Engineering Division \\ Argonne National Laboratory \\ 9700 S. Cass Avenue \\ Argonne, IL 60439 \\ USA
}




\section{Table of Contents}

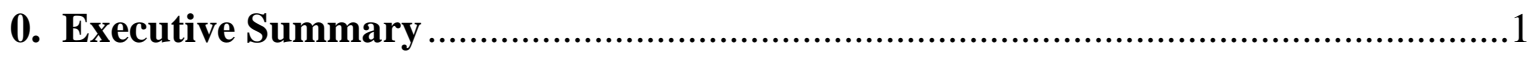

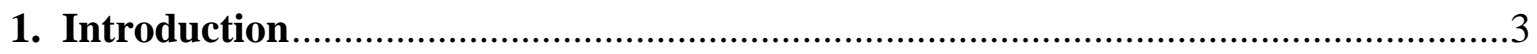

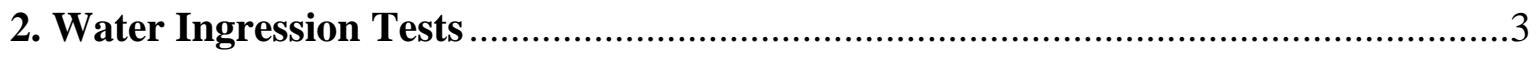

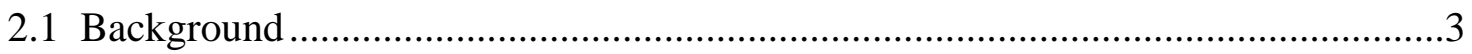

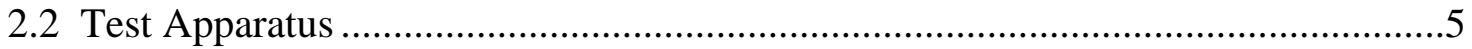

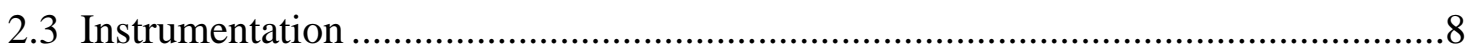

2.4 Data Acquisition and Control Systems …....................................................... 10

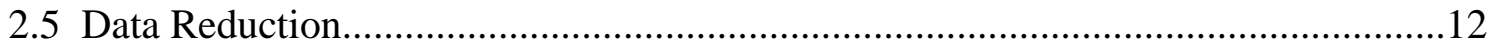

2.6 Thermal Loading Calculations..............................................................................13

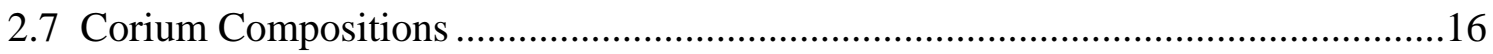

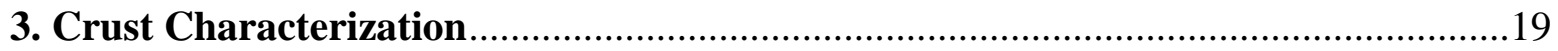

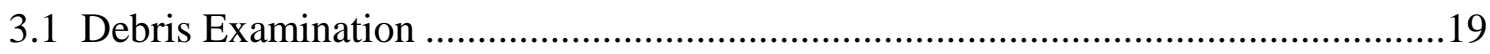

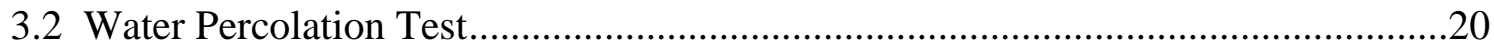

3.3 Crust Strength and Chemical Composition.......................................................20

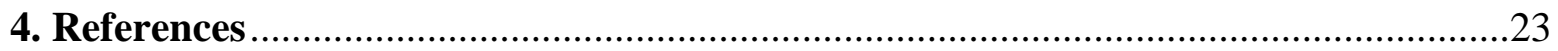

Appendix: Memo on Crust Strength Measurement .............................................24 


\section{Executive Summary}

At the first MCCI Project review meeting, the MB approved execution of the proposed water ingression tests. The test matrix for the first three experiments, as revised by the PRG and approved by the MB, is provided in Table 0.1. The objective of this report is to summarize the design of these Small Scale Water Ingression and Crust Strength (SSWICS) tests for review, modification, and/or approval by the PRG.

The methodology of the water ingression tests is to produce a prototypic core melt composition (using an exothermic chemical reaction) within a cylindrical test section over a basemat that is either concrete or an inert material. Once the melt is generated, it is flooded from above with water. The steam produced as a result of the interaction is condensed within an instrumented quench system. The corresponding melt/water heat flux is calculated from the steam condensation rate. The water ingression rate is then determined by comparing the actual heat flux to the well-known analytical solution for conduction cooling of a solid.

The solidified corium produced by the water ingression tests will be subjected to further examination. This will include documentation of the posttest debris configuration through drawings and photographs. Once the debris has been characterized, a water percolation test will be performed. This will be used to calculate the dryout heat flux, which is then compared with the value inferred from the corium quench rate data.

The rupture modulus of the crust will also be measured. This will be accomplished with an apparatus that is designed to load the sample while a temperature gradient is maintained across the crust. The apparatus can maintain a gradient of up to $1000^{\circ} \mathrm{C}$. The applied load and crust displacement are recorded during the test. Once the crust has failed and cooled to room temperature, its physical characteristics will be documented further, including chemical analysis to provide information on the axial phase distribution of the solidified material.

Table 0.2 summarizes the parameter ranges for the SSWICS facility that were developed during the design activity. At the review meeting, the project recommended that tests be conducted in a $20 \mathrm{~cm}$ ID test apparatus. Several PRG members commented that a larger diameter would be desirable to reduce sidewall effects. On this basis, the test section ID has been increased to the maximum size that does not require major revisions to the support structure. Note also that the size is limited by the need to maintain a pressure of at least 4 bar for the high pressure tests. As requested by the PRG, the facility has also been designed to accommodate up to $20 \mathrm{~cm}$ melt depth, which corresponds to $~ 100$ $\mathrm{kg}$ core melt mass in the $30.5 \mathrm{~cm}$ ID test section. As shown in the table, a wide range of melt compositions can be considered given the exothermic chemical reaction technique for producing the core melts in these tests.

\begin{tabular}{|c|c|c|l|l|}
\hline $\begin{array}{c}\text { Test } \\
\text { No. }\end{array}$ & $\begin{array}{c}\text { Melt } \\
\text { Mass (kg) }\end{array}$ & $\begin{array}{c}\text { Melt Depth } \\
(\mathbf{c m})\end{array}$ & \multicolumn{1}{|c|}{ Melt Composition } & \multicolumn{1}{|c|}{ Other parameter(s) } \\
\hline 1 & $\sim 40$ & $\sim 20$ & Fully oxidic + 8\% LCS & $\begin{array}{l}\text { Water injection rate. No decay heat, } \\
\text { inert basemat }\end{array}$ \\
\hline 2 & $\sim 40$ & $\sim 20$ & Fully oxidic + 8\% SIL & $\begin{array}{l}\text { Water injection rate. No decay heat, } \\
\text { inert basemat }\end{array}$ \\
\hline 3 & $\sim 40$ & $\sim 20$ & Fully oxidic + 8\% LCS (?) & Same, but with 2-4 bar pressure \\
\hline
\end{tabular}

Table 0.1 Water ingression tests approved by OECD/MCCI MB. 
OECD/MCCI-2002-TR01 Rev. 2

\begin{tabular}{|l|l|}
\hline \multicolumn{1}{|c|}{ Parameter } & \multicolumn{1}{c|}{ Range/Limit } \\
\hline Test section internal diameter & $30.5 \mathrm{~cm}$ \\
\hline Maximum melt depth (Volume) & $20 \mathrm{~cm}(14.6$ liters) \\
\hline Melt composition range & BWR-PWR; $50-100 \%$ oxidized, 0-50 wt \% concrete, \\
& $0-20 \mathrm{wt} \%$ structural steel or corresponding oxides. \\
\hline Melt mass at maximum depth & $100 \mathrm{~kg}^{*}$ \\
\hline Initial melt temperature & $2500^{\circ} \mathrm{C}$ \\
\hline Basemat type & Inert, or thin $(\sim 2.5 \mathrm{~cm})$ concrete \\
\hline System pressure & $1-4$ bar absolute \\
\hline Water injection flowrate & Up to 8.4 lpm $\left(5 \mathrm{MW} / \mathrm{m}^{2}\right.$ equivalent quench rate) \\
\hline Water depth & $50 \mathrm{~cm}$ \\
\hline
\end{tabular}

*The melt mass is calculated from the limiting volume assuming a melt density of $6800 \mathrm{~kg} / \mathrm{m}^{3}$.

Table 0.2 SSWICS facility test operating envelope.

The specifications for the first SSWICS experiments are provided in Table 0.3. As requested by the PRG, tests one and two are conducted with corium compositions containing nominally 8 wt \% LCS and SIL concrete, respectively. These melt compositions are noticeably similar to those employed in the MACE program, but contain a slightly higher fuel-to-cladding ratio, which is motivated by MELCOR analysis predictions for a typical PWR core melt accident progression. The $6 \mathrm{wt} \% \mathrm{Cr}$ metal present in these compositions is a byproduct of the exothermic chemical reaction used to generate the melts.

The melt depth for these tests is slightly less than that requested by the PRG (table 0.1) to accommodate posttest crust strength measurements. Still, the depth should be more than adequate to resolve dryout limits of interest in reactor safety applications, including long-term effects that could be important, such as phase segregation.

Test three differs from the first two in that the total pressure will be 3 bar. For this test, there are currently no specific recommendations for the melt composition or depth. Specific recommendations for will be provided once the results of the first two tests are available.

\begin{tabular}{|l|c|c|c|}
\hline \multicolumn{1}{|c|}{ Parameter } & SSWICS-1 & SSWICS-2 & SSWICS-3 \\
\hline Test section internal diameter $(\mathrm{cm})$ & 30.5 & 30.5 & 30.5 \\
\hline Melt composition $\left(\mathrm{wt}^{\circ} \mathrm{UO}_{2} / \mathrm{ZrO}_{2} / \mathrm{Cr} /\right.$ Concrete) & $61 / 25 / 6 / 8$ & $61 / 25 / 6 / 8$ & TBD $^{*}$ \\
\hline Concrete type & $\mathrm{LCS}$ & $\mathrm{SIL}$ & $\mathrm{TBD}$ \\
\hline Melt mass at maximum depth $(\mathrm{kg})$ & 75 & 75 & $\mathrm{TBD}$ \\
\hline Initial Melt Temperature $\left({ }^{\circ} \mathrm{C}\right)$ & $\sim 2200$ & $\sim 2200$ & TBD \\
\hline Basemat type & Inert & Inert & Inert \\
\hline System pressure (bar) & 1 & 1 & 3 \\
\hline Water injection flowrate $(\mathrm{lpm})$ & 8.4 & 8.4 & 8.4 \\
\hline Water depth $(\mathrm{cm})$ & 50 & 50 & 50 \\
\hline
\end{tabular}

* To be determined

Table 0.3 Test specifications for the first three SSWICS experiments. 


\section{Introduction}

The Melt Attack and Coolability Experiments (MACE) program at Argonne National Laboratory addressed the issue of the ability of water to cool and thermally stabilize a molten core/concrete interaction (MCCI) when the reactants are flooded from above. These tests provided data regarding the nature of corium interactions with concrete, the heat transfer rates from the melt to the overlying water pool, and the role of noncondensable gases in the mixing processes that contribute to melt quenching. However, due to the integral nature of these tests, several questions regarding the crust freezing behavior could not be adequately resolved. These questions include:

1) To what extent does water ingression into the crust increase the melt quench rate above the conduction-limited rate and how is this affected by melt composition and system pressure?

2) What is the fracture strength of the corium crust when subjected to a thermal-mechanical load and how does it depend upon the melt composition?

A series of separate-effects experiments are planned to address these issues. The first employs an apparatus designed to measure the quench rate of a pool of corium $(\sim \phi 30 \mathrm{~cm}$; up to $20 \mathrm{~cm}$ deep). The main parameter to be varied in these quench tests is the melt composition since it is thought to have a critical influence on the crust cracking behavior which, in turn, alters quench rate. A description of the test apparatus, instrumentation, data reduction, and test matrix are the subject of the first portion of this report.

The issue of crust strength will be addressed with a second apparatus designed to mechanically load the crust produced by the quench tests. This apparatus will measure the fracture strength of the crust while under a thermal load created by a heating element beneath the crust. The introduction of a thermal gradient across the crust is thought to be important for these tests because of uncertainty in the magnitude of the thermal stresses and thus their relative importance in the crust fracture mechanism at plant scale. The second half of this report describes the apparatus for measuring crust strength.

The two apparatuses used to measure the melt quench rate and crust strength are jointly referred to as SSWICS (Small-Scale Water Ingression and Crust Strength).

\section{Water Ingression Tests}

\subsection{Background}

The purpose of these experiments is to measure the boiling heat flux of corium melts flooded from above. The minimum, conduction-limited heat transfer rate from the melt to the liquid can be calculated from a well-known analytical solution. However, the actual heat flux from the melt to the overlying water layer will be somewhat greater than the conduction limit due to cracks and voids that form within the crust as it cools. Such a porous crust provides pathways for liquid to penetrate downwards, where it can provide additional cooling through a boiling 
mechanism. This liquid transport through a permeable crust towards the freezing front is known as "water ingression”.

The degree of enhanced heat transfer due to water ingression is difficult to predict analytically because of the strong dependence of the water ingression rate on the crust morphology. Also, the rate at which water percolates down through the crust is a function of the counter current steam flow rate. These rates vary with the crust morphology, which in turn depends upon the chemical composition of the crust.

The basic premise of these tests is to measure the heat flux from the melt to the overlying water layer, compare it with the analytical solution, and then determine the extent to which water ingression enhances cooling of the melt. Figure 2.1 provides a plot of the analytical solution [1] for transient cooling of a semi-infinite slab by conduction following a step change in surface temperature. In this case, the initial slab temperature is $2500^{\circ} \mathrm{C}$ and the transient is initiated by setting the surface temperature to $100^{\circ} \mathrm{C}$. The model is one-dimensional and so multidimensional effects such as heat losses are disregarded. The relevant thermo-physical properties for this calculation are the corium thermal conductivity, density, and specific heat, which are taken to be $1.5 \mathrm{~W} / \mathrm{m}^{\circ} \mathrm{C}, 7000 \mathrm{~kg} / \mathrm{m}^{3}$, and $600 \mathrm{~J} / \mathrm{kg}{ }^{\circ} \mathrm{C}$, respectively.

As shown in fig. 2.1, the conduction-limited heat flux falls off rapidly. In contrast, for a porous crust with a given morphology, the total heat transfer rate will at some point remain above that predicted by the conduction solution. This is when the heat flux departs from the conduction solution, as shown in the plot. A plateau can occur when a balance is reached in the counter current flow of liquid down to the melt quench front and steam returning up through the network

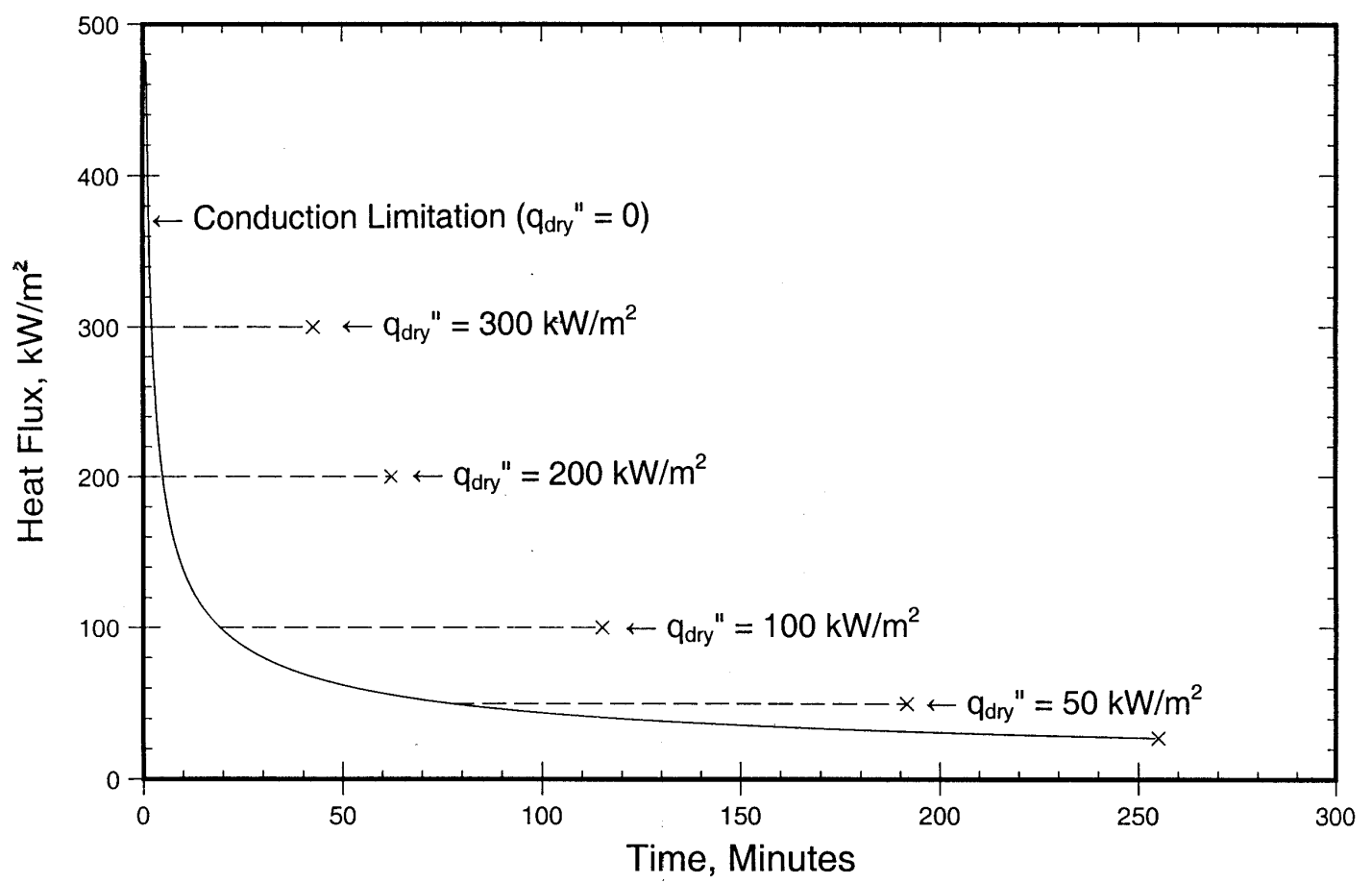

Figure 2.1 Corium cool-down rates for selected heat fluxes. 
of pores in the crust. Such a plateau in the boiling heat flux is often referred to as the "dryout" heat flux. Using the dryout flux, the debris permeability during quench can be back-calculated from models available in the literature (e.g., see Jones et al [2]).

The end points of each plot in fig. 2.1 represent the moment when the bottom of the melt reaches $100^{\circ} \mathrm{C}$ and the melt is considered quenched. A melt depth of $8 \mathrm{~cm}$ was used for these calculations. Figure 2.1 shows that a heat flux less than $\sim 30 \mathrm{~kW} / \mathrm{m}^{2}$ cannot be resolved with a melt depth of $8 \mathrm{~cm}$. This is because the entire melt is quenched before the conduction-limited heat flux falls to this level. However, such a low heat flux is not relevant to reactor safety applications. Thus, assuming the dryout limit is not a function of melt depth, increasing the depth to resolve lower limits would unnecessarily escalate program costs. However, other factors (e.g., phase segregation) may influence the water ingression rate by changing the material composition as the quench front progresses. If this is the case, a deeper melt pool is desirable in order to resolve these long term effects.

\subsection{Test Apparatus}

The SSWICS reaction vessel (RV) has been designed to hold up to $100 \mathrm{~kg}$ of melt at an initial temperature of $2500^{\circ} \mathrm{C}$. The RV lower plenum consists of a $67.3 \mathrm{~cm}$ long, $45.7 \mathrm{~cm}$ (18”) outer diameter carbon steel pipe (fig. 2.2). The pipe is insulated from the melt by a $6.4 \mathrm{~cm}$ thick layer of cast MgO. The selected pipe and insulation dimensions result in a melt diameter of $30.5 \mathrm{~cm}$ and a surface area of $730 \mathrm{~cm}^{2}$. The melt depth at the maximum charge of $100 \mathrm{~kg}$ is about $20 \mathrm{~cm}$.

The RV lower flange is insulated with a $6.4 \mathrm{~cm}$ thick slab of cast MgO that spans the entire inner diameter of the pipe. The MgO slab and sidewalls form the crucible containing the corium. This particular geometry was chosen to facilitate removal of the slab for the crust strength measurement tests. Corium has a tendency to bond with the MgO insulation and this design allows one to pry the slab away from the $\mathrm{MgO}$ walls without damaging the crust.

The MgO slab lies beneath a $1.3 \mathrm{~cm}$ thick cast $\mathrm{ZrO}_{2}$ plate. The $\mathrm{ZrO}_{2}$ is added because of its exceptionally low thermal conductivity at high temperature $\left(\sim 1 \mathrm{~W} / \mathrm{m}^{\circ} \mathrm{C}\right.$, versus $\sim 10$ for $\mathrm{MgO}$ at $2000^{\circ} \mathrm{C}$ ). Despite its low thermal conductivity, the $\mathrm{ZrO}_{2}$ is not used as the primary insulator to protect the flange because of its poor thermal shock resistance. To protect the cast $\mathrm{ZrO}_{2}$ plate from the initial thermal shock following thermite ignition, a disk of low-density $\mathrm{ZrO}_{2}$ board is set on top of the cast plate. This material is not structurally robust and serves as a sacrificial layer that absorbs the initial thermal shock of thermite ignition. Finally, a thin layer $(0.25 \mathrm{~mm})$ of tungsten is added in an effort to prevent the erosion of the $\mathrm{ZrO}_{2}$ that is expected if the corium was allowed to come in direct contact with the low-density board.

The RV upper plenum consists of a second section of pipe lined with cast MgO. Three $10 \mathrm{~cm}$ pipes welded near the top of the vessel provide 1) a vent line for the initial surge of hot noncondensable gases generated by the thermite reaction, 2) a pressure relief line with a 6 bar rupture disk, and 3) an instrument flange for the absolute pressure transmitter that measures the reaction vessel pressure. Four $6 \mathrm{~mm}(1 / 4$ ”) tubes serve as water inlets for melt quenching. A baffle is mounted below the upper flange and the water flow is directed towards the baffle to reduce the momentum of the fluid before it drops down onto the melt. The baffle is also 
OECD/MCCI-2002-TR01 Rev. 2

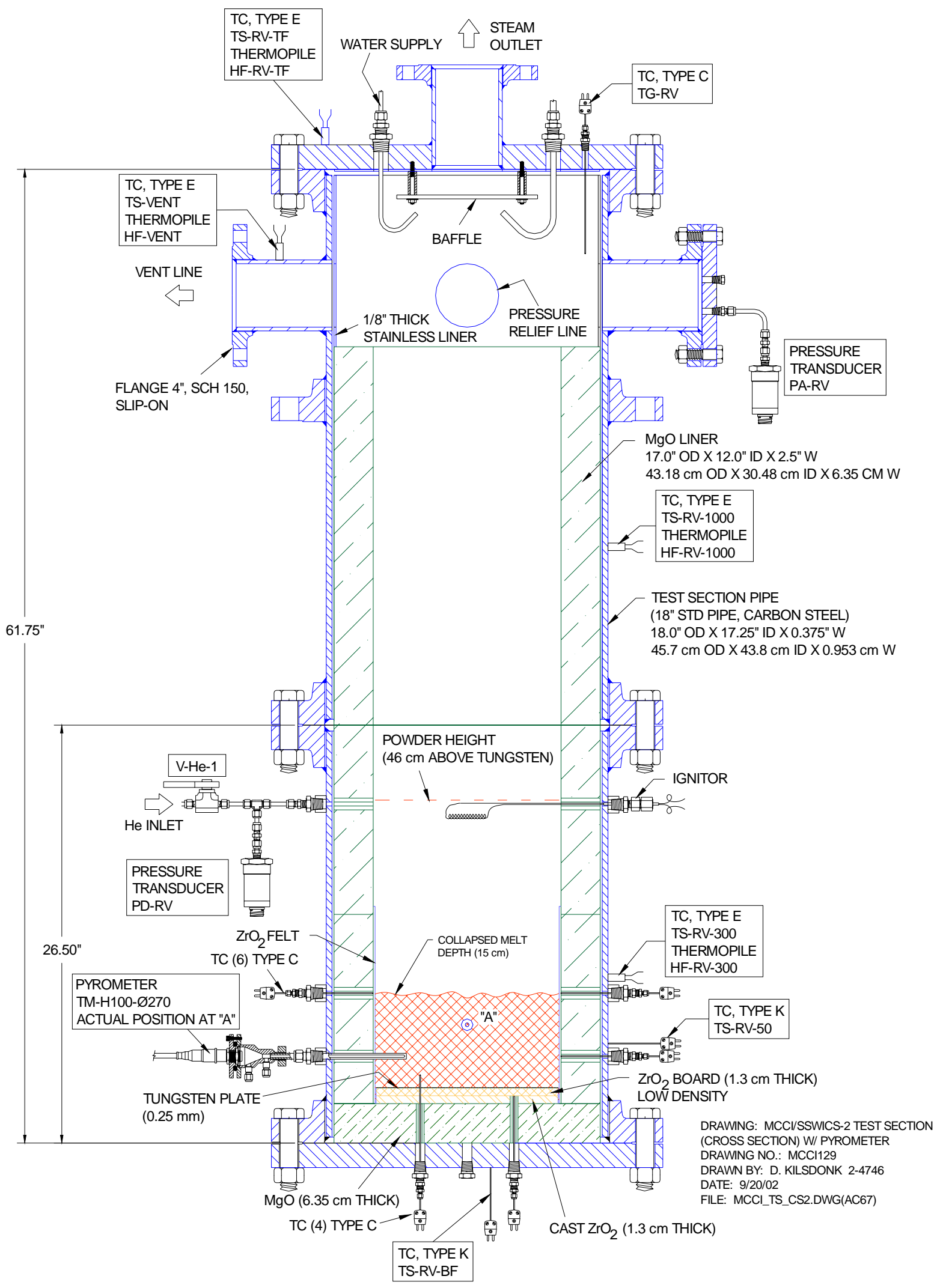

Figure 2.2 Side view of SSWICS reaction vessel for dryout heat flux measurements. 
OECD/MCCI-2002-TR01 Rev. 2

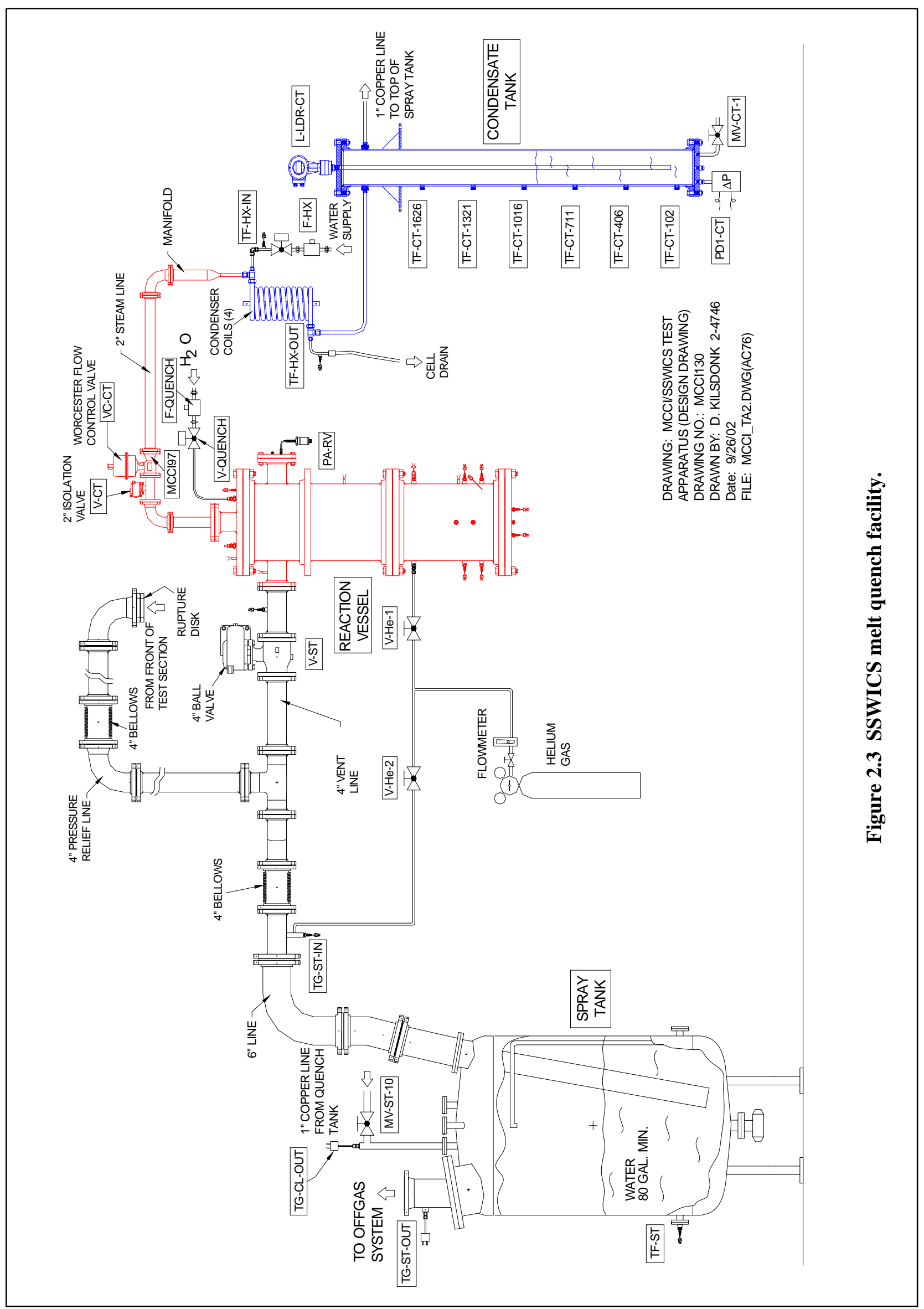


intended to prevent water droplets from being carried up towards the condenser, which would adversely affect the heat flux measurement. A fourth $10 \mathrm{~cm}$ pipe welded to the top flange provides an outlet to carry steam from the quenching melt to four cooling coils. The watercooled coils condense the steam, which is collected within a $200 \mathrm{~cm}$ high, $20 \mathrm{~cm}$ diameter condensate tank (CT). Figure 2.3 is a schematic that provides an overview of the entire SSWICS melt-quench facility.

\subsection{Instrumentation}

Instrumentation has been selected to provide all measurements necessary to determine the melt dryout heat flux. Tables 2.1 and 2.2 list the sensors and major valves, respectively.

The critical measurement for these tests is the steaming rate in the RV, which is found indirectly by measuring the rate of condensate collection in the CT. Because of the importance of this measurement, it is determined with two independent sensors: 1) a differential pressure sensor at the base of the tank to measure the mass of the condensate and 2) a time domain reflectometer to measure the liquid level.

The remaining instrumentation provides supplementary information to further characterize the test conditions. The initial melt temperature is provided by two Type- $C$ thermocouples located $20 \mathrm{~mm}$ above the bottom of the melt and $7.5 \mathrm{~cm}$ from the RV centerline (halfway to the MgO wall). A second pair of type-C thermocouples below the $\mathrm{ZrO}_{2}$ board and near the bottom of the melt is used to detect the arrival of the quench front. The melt is considered quenched when the temperature at the base of the melt reaches the saturation temperature, and this is the basis for terminating the test.

A pyrometer is used for an additional melt temperature measurement. The pyrometer measures the temperature at the bottom of a tungsten thermowell, which is positioned so that the tip is located $100 \mathrm{~mm}$ above the bottom of the melt and $50 \mathrm{~mm}$ from the inner wall of the MgO liner (i.e. $50 \mathrm{~mm}$ into the melt).

There are a total of eight fittings near the base of the RV for radial instrument penetrations. One is reserved for the pyrometer. The remaining seven are used for thermocouples that are positioned at the outer edge of the melt to determine whether water seeps between the MgO wall and the crust as it forms above the melt. Though such seepage is deemed unlikely, this must be verified because the dryout heat flux measurement would be compromised by a melt that was partially cooled by water circumventing the crust.

Positioning of the thermocouples was influenced by the needs of the posttest crust strength measurements. The thermocouples measuring the initial melt temperature penetrate only $2 \mathrm{~cm}$ through the bottom of the melt to minimize alteration of the crust mechanical properties. In addition, there are no penetrations of any sort near the center of the melt because this is the most likely location of crust failure (see appendix). 
OECD/MCCI-2002-TR01 Rev. 2

\begin{tabular}{|c|c|c|c|c|c|c|c|c|}
\hline$\#$ & Channel & Name & Type & Description & Serial \# & Output & Range & Accuracy \\
\hline 0 & HPS-0 & T-CJ-HPS & AD592 IC & Cold junction compensation sensor. & - & $1 \mu \mathrm{A} / \mathrm{K}$ & $0-70^{\circ} \mathrm{C}$ & A $0.5^{\circ} \mathrm{C}$ \\
\hline 1 & HPS-1 & TM-H0- $\phi 90$ & TC type $C$ & Melt temp. at bottom of melt. & - & $0-37 \mathrm{mV}$ & $0-2320^{\circ} \mathrm{C}$ & A $4.5^{\circ} \mathrm{C}$ or $1 \%$ \\
\hline 2 & HPS-2 & TM-H0- $\phi 270$ & TC type C & Melt temp. at bottom of melt. & - & $0-37 \mathrm{mV}$ & $0-2320^{\circ} \mathrm{C}$ & A $4.5^{\circ} \mathrm{C}$ or $1 \%$ \\
\hline 3 & HPS-3 & TM-H20- $\phi 0$ & TC type C & Melt temp. $20 \mathrm{~mm}$ above bottom of melt. & - & $0-37 \mathrm{mV}$ & $0-2320^{\circ} \mathrm{C}$ & A $4.5^{\circ} \mathrm{C}$ or $1 \%$ \\
\hline 4 & HPS-4 & TM-H20- $\phi 180$ & TC type $\mathrm{C}$ & Melt temp. $20 \mathrm{~mm}$ above bottom of melt. & - & $0-37 \mathrm{mV}$ & $0-2320^{\circ} \mathrm{C}$ & A $4.5^{\circ} \mathrm{C}$ or $1 \%$ \\
\hline 5 & HPS-5 & TIW-H50- $\phi 0$ & TC type C & Melt temp. at inner sidewall $50 \mathrm{~mm}$ above bottom of melt. & - & $0-37 \mathrm{mV}$ & $0-2320^{\circ} \mathrm{C}$ & A $4.5^{\circ} \mathrm{C}$ or $1 \%$ \\
\hline 6 & HPS-6 & TIW-H50- $\phi 180$ & TC type C & Melt temp. at inner sidewall $50 \mathrm{~mm}$ above bottom of melt. & - & $0-37 \mathrm{mV}$ & $0-2320^{\circ} \mathrm{C}$ & A $4.5^{\circ} \mathrm{C}$ or $1 \%$ \\
\hline 7 & HPS-7 & TIW-H100- $\phi 90$ & TC type $\mathrm{C}$ & Melt temp. at inner sidewall $100 \mathrm{~mm}$ above bottom of melt. & - & $0-37 \mathrm{mV}$ & $0-2320^{\circ} \mathrm{C}$ & A $4.5^{\circ} \mathrm{C}$ or $1 \%$ \\
\hline 8 & HPS-8 & TIW-H150-ф0 & TC type C & Melt temp. at inner sidewall $150 \mathrm{~mm}$ above bottom of melt. & - & $0-37 \mathrm{mV}$ & $0-2320^{\circ} \mathrm{C}$ & $\mathrm{A}^{4.5^{\circ} \mathrm{C} \text { or } 1 \%}$ \\
\hline 10 & HPS-10 & TM-H200- $\phi 90$ & TC type C & Melt temp. at inner sidewall $200 \mathrm{~mm}$ above bottom of melt. & - & $0-37 \mathrm{mV}$ & $0-2320^{\circ} \mathrm{C}$ & A $4.5^{\circ} \mathrm{C}$ or $1 \%$ \\
\hline 11 & HPS-11 & TM-H200- $\phi 270$ & TC type C & Melt temp. at inner sidewall $200 \mathrm{~mm}$ above bottom of melt. & - & $0-37 \mathrm{mV}$ & $0-2320^{\circ} \mathrm{C}$ & A $4.5^{\circ} \mathrm{C}$ or $1 \%$ \\
\hline 12 & HPS-12 & TG-RV & TC type C & Gas temp. in reaction vessel upper plenum. & - & $0-37 \mathrm{mV}$ & $0-2320^{\circ} \mathrm{C}$ & A $4.5^{\circ} \mathrm{C}$ or $1 \%$ \\
\hline 13 & HPS-13 & TS-RV-300 & TC type E & Outer wall temp. of RV $300 \mathrm{~mm}$ above bottom of melt. & - & $0-70 \mathrm{mV}$ & $0-900^{\circ} \mathrm{C}$ & A $1.7^{\circ} \mathrm{C}$ or $0.5 \%$ \\
\hline 14 & HPS-14 & TS-RV-1000 & TC type $\mathrm{E}$ & Outer wall temp. of RV $1000 \mathrm{~mm}$ above bottom of melt. & - & $0-70 \mathrm{mV}$ & $0-900^{\circ} \mathrm{C}$ & A $1.7^{\circ} \mathrm{C}$ or $0.5 \%$ \\
\hline 15 & HPS-15 & TS-RV-tf & TC type E & Temperature of RV top flange & - & $0-70 \mathrm{mV}$ & $0-900^{\circ} \mathrm{C}$ & A $1.7^{\circ} \mathrm{C}$ or $0.5 \%$ \\
\hline 16 & HPS-16 & TS-vent & TC type E & Outer wall temp. of vent line. & - & $0-70 \mathrm{mV}$ & $0-900^{\circ} \mathrm{C}$ & A $1.7^{\circ} \mathrm{C}$ or $0.5 \%$ \\
\hline 17 & HPS-17 & TS-RV-bf & TC type $\mathrm{K}$ & Temperature of RV bottom flange. & - & $0-50 \mathrm{mV}$ & $0-1250^{\circ} \mathrm{C}$ & A $2.2^{\circ} \mathrm{C}$ or $0.75 \%$ \\
\hline 18 & HPS-32 & TS-RV-50 & TC type K & Outer wall temp. of RV $50 \mathrm{~mm}$ above bottom of melt. & - & $0-50 \mathrm{mV}$ & $0-1250^{\circ} \mathrm{C}$ & A $2.2^{\circ} \mathrm{C}$ or $0.75 \%$ \\
\hline 20 & HPS-19 & TF-CT-406 & TC type $\mathrm{K}$ & Fluid temp. in condensate tank at a water level of $406 \mathrm{~mm}$. & - & $0-50 \mathrm{mV}$ & $0-1250^{\circ} \mathrm{C}$ & A $2.2^{\circ} \mathrm{C}$ or $0.75 \%$ \\
\hline 21 & HPS-20 & TF-CT-711 & TC type K & Fluid temp. in condensate tank at a water level of $711 \mathrm{~mm}$. & - & $0-50 \mathrm{mV}$ & $0-1250^{\circ} \mathrm{C}$ & $\mathrm{A} 2.2^{\circ} \mathrm{C}$ or $0.75 \%$ \\
\hline 22 & HPS-21 & TF-CT-1016 & TC type $\mathrm{K}$ & Fluid temp. in condensate tank at a water level of $1016 \mathrm{~mm}$. & - & $0-50 \mathrm{mV}$ & $0-1250^{\circ} \mathrm{C}$ & A $2.2^{\circ} \mathrm{C}$ or $0.75 \%$ \\
\hline 23 & HPS-22 & TF-CT-1321 & TC type $\mathrm{K}$ & Fluid temp. in condensate tank at a water level of $1321 \mathrm{~mm}$. & - & $0-50 \mathrm{mV}$ & $0-1250^{\circ} \mathrm{C}$ & A $2.2^{\circ} \mathrm{C}$ or $0.75 \%$ \\
\hline 24 & HPS-23 & TF-CT-1626 & TC type K & Fluid temp. in condensate tank at a water level of $1626 \mathrm{~mm}$. & - & $0-50 \mathrm{mV}$ & $0-1250^{\circ} \mathrm{C}$ & A $2.2^{\circ} \mathrm{C}$ or $0.75 \%$ \\
\hline 25 & HPS-24 & TF-HX-in & TC type $\mathrm{K}$ & Fluid temp. at HX coolant inlet. & - & $0-50 \mathrm{mV}$ & $0-1250^{\circ} \mathrm{C}$ & A $2.2^{\circ} \mathrm{C}$ or $0.75 \%$ \\
\hline 26 & HPS-25 & TF-HX-out & TC type $\mathrm{K}$ & Fluid temp. at HX coolant outlet. & - & $0-50 \mathrm{mV}$ & $0-1250^{\circ} \mathrm{C}$ & A $2.2^{\circ} \mathrm{C}$ or $0.75 \%$ \\
\hline 27 & HPQ-51 & TF-ST & TC type $\mathrm{K}$ & Fluid temp. in spray tank. & - & $0-50 \mathrm{mV}$ & $0-1250^{\circ} \mathrm{C}$ & $\mathrm{A} 2.2^{\circ} \mathrm{C}$ or $0.75 \%$ \\
\hline 28 & HPQ-53 & TG-ST-in & TC type $\mathrm{K}$ & Gas temp. in the spray tank line inlet. & - & $0-50 \mathrm{mV}$ & $0-1250^{\circ} \mathrm{C}$ & A $2.2^{\circ} \mathrm{C}$ or $0.75 \%$ \\
\hline 29 & HPQ-54 & TG-ST-out & TC type $\mathrm{K}$ & Gas temp. in the spray tank line outlet. & - & $0-50 \mathrm{mV}$ & $0-1250^{\circ} \mathrm{C}$ & A $2.2^{\circ} \mathrm{C}$ or $0.75 \%$ \\
\hline 30 & HPS-26 & HF-RV-300 & Thermopile & Heat Flux through RV wall $300 \mathrm{~mm}$ above bottom flange. & 0629 & $0-5.72 \mathrm{mV}$ & $0-5 \mathrm{~kW} / \mathrm{m}^{2}$ & A $3 \%$ \\
\hline 31 & HPS-27 & HF-RV-1000 & Thermopile & Heat Flux through RV wall 1000 mm above bottom of flange. & 0630 & $0-5.19 \mathrm{mV}$ & $0-5 \mathrm{~kW} / \mathrm{m}^{2}$ & A $3 \%$ \\
\hline 32 & HPS-28 & HF-RV-tf & Thermopile & Heat Flux through RV top flange. & 0631 & $0-5.56 \mathrm{mV}$ & $0-5 \mathrm{~kW} / \mathrm{m}^{2}$ & A $3 \%$ \\
\hline 33 & HPS-29 & HF-vent & Thermopile & Heat Flux through connecting line to V-ST. & 0632 & $0-5.50 \mathrm{mV}$ & $0-5 \mathrm{~kW} / \mathrm{m}^{2}$ & A $3 \%$ \\
\hline 34 & HPS-30 & TM-H100- $\phi 270$ & Pyrometer & Melt temp. $50 \mathrm{~mm}$ from sidewall, $100 \mathrm{~mm}$ above bottom of melt. & - & $4-20 \mathrm{~mA}$ & $1200-3000^{\circ} \mathrm{C}$ & A $0.3 \%$ \\
\hline 35 & HPS-31 & I-ign & DC supply & Current supply for thermite ignitor. & - & $0-100 \mathrm{mV}$ & 0-25 Amps & - \\
\hline 36 & HPS-33 & PA-RV & $1810 \mathrm{AZ}$ & Absolute pressure in reaction vessel. & 2 & $0-12 \mathrm{~V}$ & $0-4$ bar & A 0.03 bar \\
\hline
\end{tabular}

Table 2.1 Instrumentation list for water ingression tests (part 1 of 2). 
OECD/MCCI-2002-TR01 Rev. 2

\begin{tabular}{|c|c|c|c|c|c|c|c|c|}
\hline$\#$ & Channel & Name & Type & Description & Serial \# & Output & Range & Accuracy \\
\hline 37 & HPS-34 & PD-RV & $1801 \mathrm{DZ}$ & $\Delta \mathrm{P}$ : Atmospheric pressure - pressure $450 \mathrm{~mm}$ above bottom of melt. & D-2 & $0-13 \mathrm{~V}$ & 0-0.35 bar & A 0.004 bar \\
\hline 38 & HPS-35 & PD-CT & $1801 \mathrm{DZ}$ & $\Delta \mathrm{P}$ transmitter to measure condensate inventory. & D-9 & $0-13 \mathrm{~V}$ & 0-0.35 bar & A 0.004 bar \\
\hline 39 & HPS-36 & L-TDR-CT & BM100A & Time domain reflectometer to measure CT level. & - & $4-20 \mathrm{~mA}$ & $0-2 \mathrm{~m}$ & A $3 \mathrm{~mm}$ \\
\hline 40 & HPS-37 & VDC-P-supply & - & Voltage of the power supply for the pressure transmitters. & - & $0-15 \mathrm{~V}$ & - & - \\
\hline 41 & HPQ-50 & T-CJ-HPQ & AD592 IC & Cold junction compensation sensor. & - & $1 \mu \mathrm{A} / \mathrm{K}$ & $0-70^{\circ} \mathrm{C}$ & A $0.5^{\circ} \mathrm{C}$ \\
\hline 42 & HPQ-52 & TG-CL-out & TC type K & Gas temperature in condensate tank outlet line to spray tank. & - & $0-50 \mathrm{mV}$ & $0-1250^{\circ} \mathrm{C}$ & A $2.2^{\circ} \mathrm{C}$ or $0.75 \%$ \\
\hline 43 & HPQ-55 & F-quench & Paddlewheel & Flow rate of cold water to heat exchangers. & 3143 & $0-5 \mathrm{~V}$ & $0-50 \mathrm{gpm}$ & A $0.5 \mathrm{gpm}$ \\
\hline 44 & HPQ-56 & F-HX & Paddlewheel & Flow rate of water into reaction vessel (for quenching melt). & 3180 & $0-5 \mathrm{~V}$ & 0-18 gpm & A 0.18 gpm \\
\hline
\end{tabular}

Table 2.2 Instrumentation list for water ingression tests (part 2 of 2).

\begin{tabular}{|c|l|l|l|l|c|}
\hline \multicolumn{2}{|c|}{ Channel \# } & \multicolumn{1}{|c|}{ Valve Name } & Type & Description & Actuator \\
\hline 1 & & V-CT & Ball valve & Valve on steam line between reaction vessel and quench tank. & Pneumatic \\
\hline 2 & & V-quench & Ball valve & Valve on quench water supply line into reaction vessel. & Solenoid \\
\hline 3 & & V-H2O-i & Ball valve & Isolation valve on quench water supply line into reaction vessel. & Solenoid \\
\hline 4 & & V-H2O-b & Ball valve & Bypass valve on quench water supply line into reaction vessel. & Solenoid \\
\hline 5 & & V-ST & Ball valve & Valve on vent line between reaction vessel and spray tank. & Pneumatic \\
\hline- & & V-HX & Ball valve & Valve on cooling-water line to heat exchangers. & Solenoid \\
\hline
\end{tabular}

Table 2.3 Remotely operated valves.

Four heat flux meters are used to obtain direct measurements of local heat losses. Two sensors are attached to the side of the RV, a third to the top flange, and the fourth is mounted to the 4" vent line between the RV and valve V-ST. The entire RV will be insulated from the melt level upwards. Though the insulation around the upper plenum should ensure that heat losses are small compared to the heat transfer rate through the cooling coils, the heat flux sensors provide an added reduction in uncertainty in the energy balance used to calculate heat flux from the corium melt. The lower $25 \mathrm{~cm}$ of the RV will be left uninsulated so that any excessive wall heating or corium breach can be readily observed. Such an occurrence would require immediate depressurization of the RV in the case of the pressurized tests.

\subsection{Data Acquisition and Control Systems}

All data acquisition and process control tasks are managed by a PC executing LabVIEW 6.i under Windows XP. Sensor output terminals are connected to model HP E1345A 16-channel multiplexers and the signals are digitized by an HP E1326B 5 1/2 digit multimeter located within the test cell (fig. 2.4). Signal noise is reduced by integration over a single power line cycle (16.7 $\mathrm{ms})$. The digitized sensor readings are routed from the test cell to the PC in the control room via two HP-IB extenders. The extenders allow the ASCII data from the HP to be sent through the cell wall over a BNC cable. The extender within the control room then communicates with a 
OECD/MCCI-2002-TR01 Rev. 2

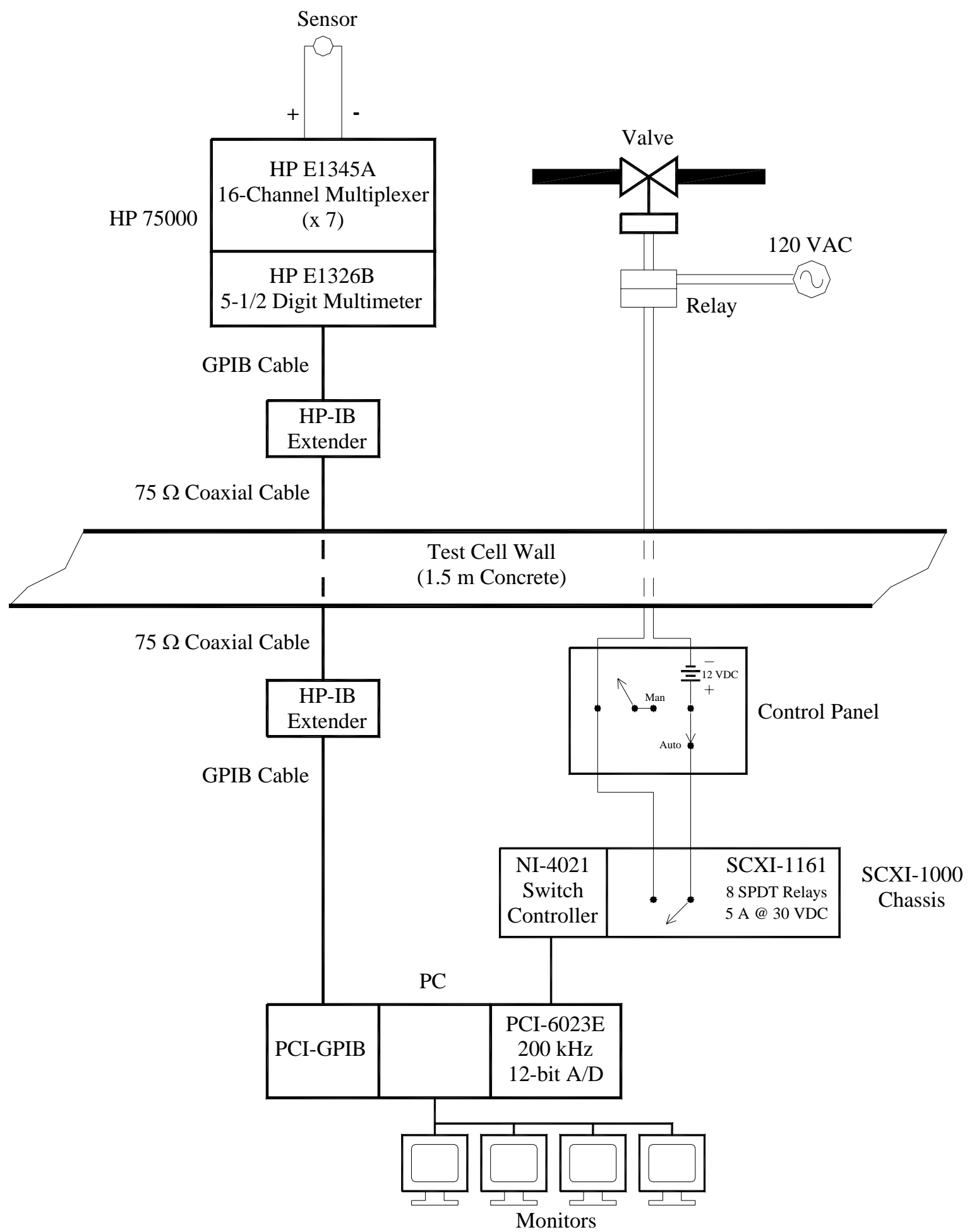

Figure 2.4 Data acquisition and control systems. 
GPIB card within the PC. This configuration also permits remote control of the multimeter through LabVIEW. The power line cycle integration results in a minimum (theoretical) time of $0.75 \mathrm{~s}$ to scan the channel list ( $16.7 \mathrm{~ms} * 45$ channels). In practice, however, the acquisition of a single scan is at a frequency of approximately $0.5 \mathrm{~Hz}$.

Valves are controlled with the PC using a relay card housed within an SCXI chassis (National Instruments). These electromechanical relays are capable of switching up to $8 \mathrm{~A}$ at $125 \mathrm{VAC}$ or $5 \mathrm{~A}$ at 30 VDC. They are operated via a switch controller in the SCXI chassis, which communicates with the PC through a general-purpose data acquisition card. As shown in fig. 2.4, the relays in the control room operate devices within the test cell indirectly, through a second relay. This is intended to provide an additional level of electrical isolation between the NI switching hardware and high voltage sources within the cell. As an added safety measure, all wiring is routed through a control panel that can be switched from automatic (PC) control to manual control in the event of computer failure. The system is currently configured to operate eight relays, but expansion to 24 is possible.

For the tests at elevated pressure, it is necessary to both measure and regulate the RV pressure. This is accomplished with a control valve operated with feedback from a PID controller. The PID controller uses the selected RV set point pressure and output from a pressure transmitter to regulate the valve position in a closed feedback loop.

\subsection{Data Reduction}

The time-dependent heat flux from the melt to the overlying water layer is calculated from an energy balance using the measured CT condensate inventory. It includes any sensible heat necessary to heat the liquid to the saturation temperature $\Delta T$, energy to vaporize the liquid, energy absorbed by the structures of the RV upper plenum, and heat losses from the upper plenum. In this context, "upper plenum" refers to all structures above the surface of the melt. The total heat transfer rate through the corium surface to the overlying water is written as:

$$
Q=M_{R V} c_{p} \frac{\partial T}{\partial t}+\dot{m} h_{f g}+\left.\left[M_{S} c_{M} \frac{\partial T}{\partial t}+Q_{H L}\right]\right|_{u p}
$$

where $M_{R V}$ is the RV liquid inventory, $\dot{m}$ is mass flow rate of condensate into the CT, $M_{S}$ is the mass of the RV upper plenum structures, $c_{m}$ their heat capacity, and $Q_{H L}$ represents total upper plenum heat losses. Note that no other parameters are necessary to determine the heat flux through the melt surface. Both the melt initial temperature and energy deposited into the RV lower plenum are immaterial in ascertaining the energy transfer rate through the melt surface. Axial conduction of energy around the melt pool via the RV walls is predicted to be small and has been neglected in the formulation above. It will, however, be included in the uncertainty analysis of the measured quench heat flux.

In practice, the energy balance above can be simplified by considering the system only after it has reached a steady state. There is an initial stage of each test where water is added to the system. Once the flow is terminated, the water pool above the melt soon reaches the saturation temperature and begins boiling. If no more water is added to the system, the first term in 
equation 2.1 can be neglected. The third term in equation 2.1 can be neglected if the structure temperatures have reached a steady state. The energy balance is most accurate when the structure temperatures are constant because even modest temperature changes involve relatively large amounts of energy.

Two independent sensors are used to measure the mass flow rate required to solve equation 2.1. The first sensor is a differential pressure transmitter and the signal is proportional to the water head so that:

$$
\dot{m}=\frac{1}{g} \frac{\pi}{4} D^{2} \frac{\partial \Delta P}{\partial t}
$$

where D refers to the inner diameter of the CT. In contrast, the time domain reflectometer directly measures the location of the condensate surface so that the liquid level $\mathrm{L}$ can be determined. The mass flow rate from the TDR is then give by:

$$
\dot{m}=\rho \frac{\pi}{4} D^{2} \frac{\partial L}{\partial t}
$$

Because of the density term in the above equation it will be necessary to measure the fluid temperature within the CT to ensure an accurate determination of the mass flow rate.

The heat flux from the corium to the water pool will also be calculated with an energy balance across the heat exchanger. The measured parameters will be the coolant flow rate on the secondary side of the cooling coils and the inlet and outlet coolant temperatures. The cooling power of the heat exchanger is then:

$$
Q_{H X}=\dot{m}_{H X} c_{p}\left(T_{\text {out }}-T_{\text {in }}\right)
$$

\subsection{Thermal Loading Calculations}

Several tests will be conducted with an elevated system pressure and for this reason it is necessary to perform a comprehensive analysis of the thermal loading on the walls of the RV that serve as the pressure boundary. The analysis must confirm that the wall temperature remains below the allowable limit for a specified working pressure. The maximum pressure expected for these tests is 4 bar. The reaction vessel is rated for 4.5 bar at $480^{\circ} \mathrm{C}$ and has been hydro tested to 13 bar at ambient temperature.

A 3-D model of the RV has been constructed using the thermal analyzer SINDA/G, which includes both a CAD-type program for preparing the model and a finite-difference code to solve steady state and transient heat transfer problems. Figure 2.5 depicts the model created for the lower plenum of the RV. Also provided is a table listing the thermal properties and dimensions used in the transient calculations (table 2.3). Symmetry has been used to reduce the size of the model to $1 / 4$ of the RV. Also, some components have been omitted to simplify construction with the CAD interface. These include the mating flange that is welded to the pipe and most of the $\mathrm{RV}$ wall above the corium. However, the only significant effect of such omissions is to increase calculated peak temperatures because additional heat capacity has been neglected. For this reason, the simplifications serve to make the calculations more conservative. 
The initial conditions chosen for the calculation are $2500^{\circ} \mathrm{C}$ for the corium and $20^{\circ} \mathrm{C}$ for all remaining components. Heat losses from the vessel wall and flange were calculated using a natural convection heat transfer coefficient of $10 \mathrm{~W} / \mathrm{m}^{2}{ }^{\circ} \mathrm{C}$. Calculations were performed for two cases. The first is a "dry" melt in which the surface of the melt is treated as an adiabatic boundary. This is considered the worst case for thermal loading since all the energy of the melt must be absorbed by the insulation and then dissipated through the pipe wall and lower flange. The second case includes simulated water cooling of the melt by allowing heat losses from the melt surface. The chosen heat transfer coefficient is $1 \mathrm{~kW} / \mathrm{m}^{2}{ }^{\circ} \mathrm{C}$ and the sink temperature is the saturation temperature of water at atmospheric pressure, i.e., $100^{\circ} \mathrm{C}$. This heat transfer coefficient is a conservative choice for boiling heat transfer, which means that the calculated cool-down is slightly slower than that expected for the actual test.

The results of the calculations are shown in fig. 2.6. The plot shows the temperature versus elapsed time at three locations of interest (see fig. 2.5). The location designated $T_{c}$ is the center of the corium melt, which is the hottest point during the transient. The locations $T_{w 1}$ and $T_{w 2}$ are the hottest points of the pipe wall during the dry and water-cooled tests, respectively. For the worst case of no water cooling, the peak wall temperature is about $450^{\circ} \mathrm{C}$, which is reached 2 hours after thermite ignition. For the case of water cooling, which is the relevant case for assessing stresses at high pressure since it is the steam that generates the pressure, the peak wall temperature is reduced to about $325^{\circ} \mathrm{C}$. The calculation demonstrates that the wall temperature should remain well below the $480^{\circ} \mathrm{C}$ limit for 4.5 bar. Considering the conservative assumptions used in this calculation (maximum initial melt inventory and temperature, only conduction cooling of the melt), we are confident that the RV integrity will not be compromised if the MgO insulation remains structurally sound.

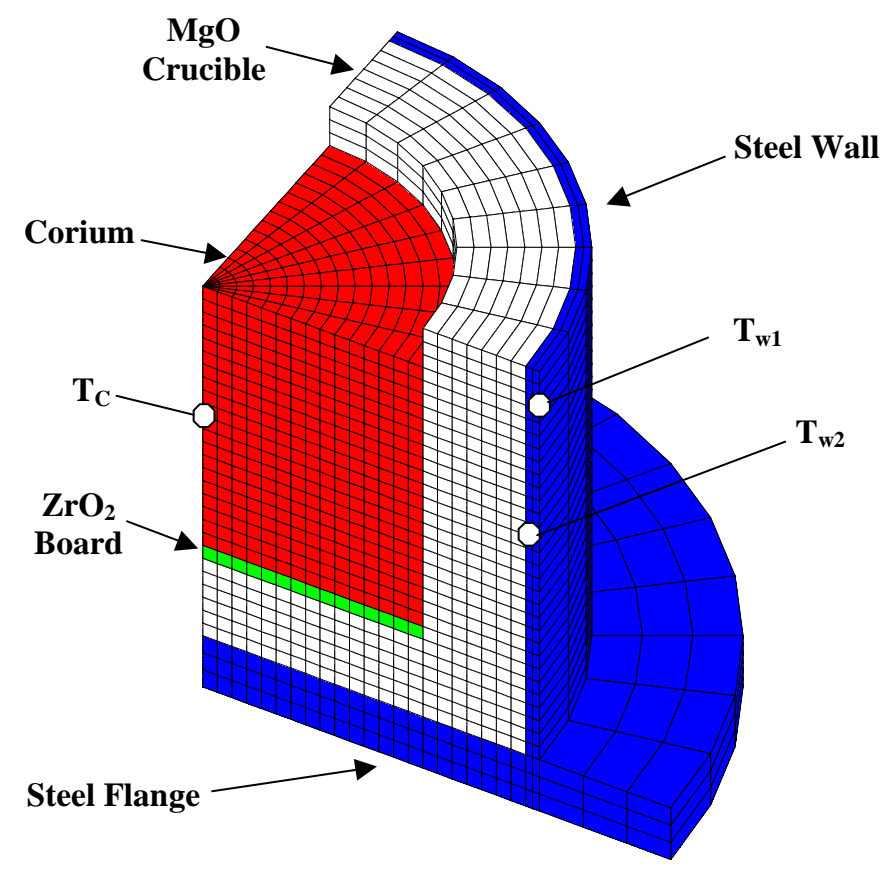

Figure 2.5 Model of reaction vessel lower plenum for SINDA/G 


\begin{tabular}{|c|c|c|c|c|c|}
\hline Component & Material & $\begin{array}{l}\text { Dimensions } \\
\text { (cm) }\end{array}$ & $\begin{array}{c}\mathrm{c}_{p_{p}} \\
\left(\mathrm{~J} / \mathrm{kg}^{0} \mathrm{C}\right)\end{array}$ & $\begin{array}{c}\mathbf{k} \\
\left(W / \mathbf{m}^{0} \mathrm{C}\right)\end{array}$ & $\begin{array}{c}\rho \\
\left(\mathrm{kg} / \mathrm{m}^{3}\right)\end{array}$ \\
\hline Pipe Wall & Carbon Steel & $\phi 45.7 \times 30 \times 0.95$ & 419. & 47. & 3580. \\
\hline Lower Flange & Carbon Steel & $\phi 635 \times 4$ & 419. & 47. & 3580. \\
\hline Corium & $\mathrm{UO}_{2}$ & $\phi 30 \times 20$ & 600. & 1.5 & 7000 . \\
\hline Insulating Board & $\mathrm{ZrO}_{2}$ & $\phi 30 \times 1$ & 620. & 1.2 & 5500. \\
\hline Sidewall Insulation & $\mathrm{MgO}$ & $\phi 43.8 \times 24 \times 7$ & 1260. & 10. & 3580. \\
\hline Flange Insulation & $\mathrm{MgO}$ & $\phi 43.8 \times 6$ & 1260. & 10. & 3580. \\
\hline
\end{tabular}

Table 2.3 Material properties used for SINDA/G calculations.

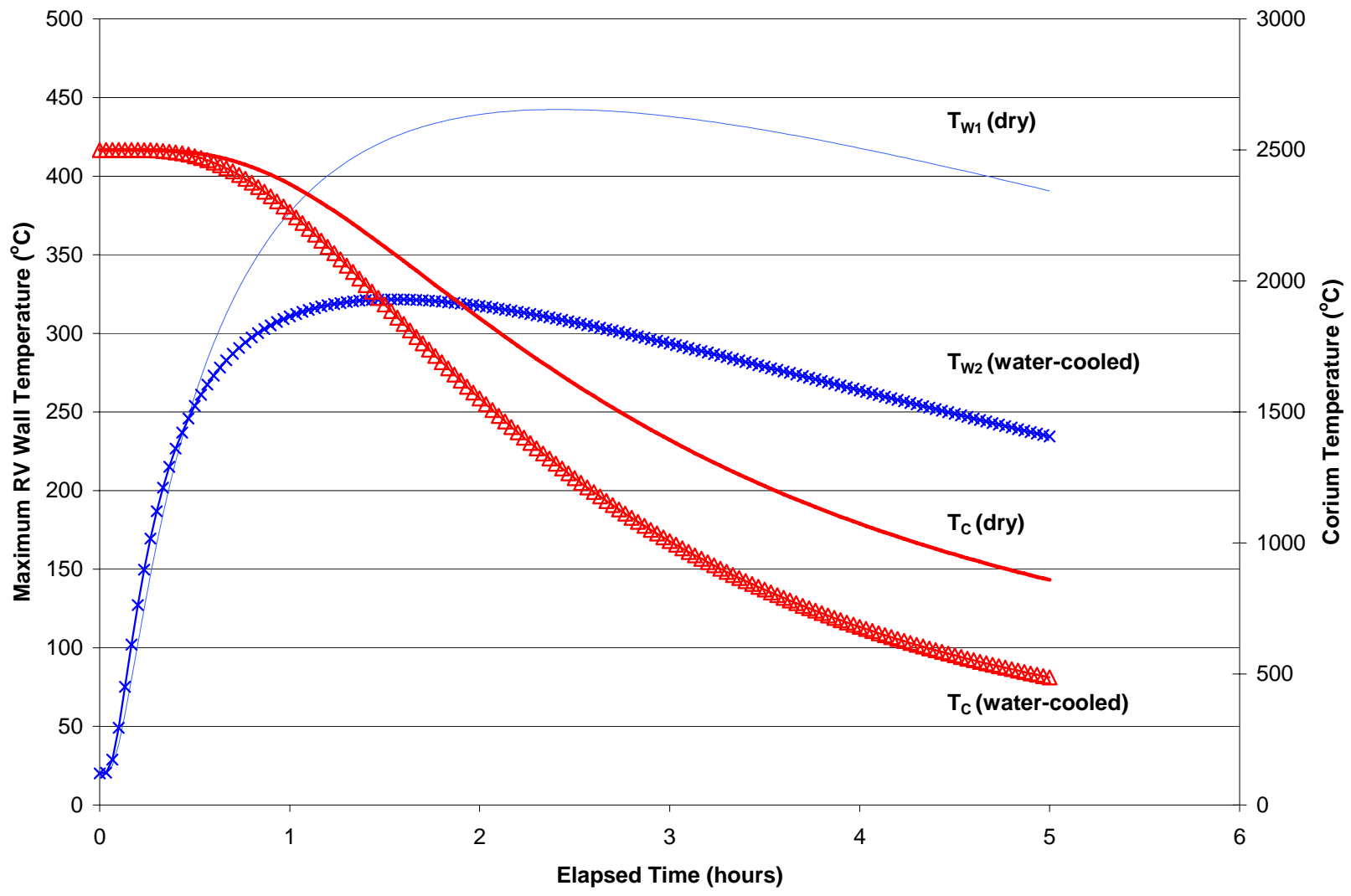

Figure 2.6 Calculated corium and RV wall temperatures versus elapsed time. 


\subsection{Corium Compositions}

The PRG has requested that the first two SSWICS tests be conducted with corium compositions reflecting interaction with limestone/common sand and siliceous concrete basemats. For these first tests, it is recommended to utilize thermite compositions that are similar to those developed as part of the MACE program for generating melts with these particular concretes initially present. The reasoning for this is as follows: 1) water ingression and crust strength data obtained for these two compositions will aid in interpreting previous MACE test results, and 2) the thermite mixtures that produce these compositions have been fully tested and qualified for use in these types of tests so that minimal developmental work is required.

The thermite used in the MACE program to produce a fully oxidized core melt containing nominally $8.5 \mathrm{wt} \%$ limestone/common sand (LCS) concrete at $\sim 2030^{\circ} \mathrm{C}$ is shown in table 2.4 . It contains a slightly lower core-to-cladding oxide ratio in comparison to the target composition for SSWICS-1, which is shown in table 0.3. The thermite described in table 2.4 will be modified slightly to produce the SSWICS-1 target composition.

The thermite used in the MACE tests to produce a core melt containing $8.5 \mathrm{wt} \%$ siliceous concrete (SIL) is shown in table 2.5. This particular thermite also produces a melt composition containing a slightly lower core-to-cladding oxide ratio in comparison to the target for SSWICS2 , which is shown in table 0.3 . This thermite will also be modified slightly to produce the target composition.

In regards to potential melt compositions for future SSWICS tests, note that a wide range of compositions can be produced using the exothermic chemical reaction technique. As indicated above, a metallic byproduct is produced in thermitically-generated corium melts. This byproduct can be Fe, Cr, Mo, or a mixture thereof. For the SSWICS-1 and SSWICS-2 thermites, $\mathrm{CrO}_{3}$ is employed as the oxidizer, which yields $\mathrm{Cr}$ metal as the reaction byproduct. The advantage of this very strong oxidizer is that it minimizes the amount of extraneous metal produced as a result of the reaction.

\begin{tabular}{|c|c|c|}
\hline Constituent & $\begin{array}{c}\text { Reactant } \\
\text { (wt \%) }\end{array}$ & $\begin{array}{c}\text { Product } \\
\text { (wt \%) }\end{array}$ \\
\hline $\mathrm{U}_{3} \mathrm{O}_{8}$ & 59.4 & - \\
\hline $\mathrm{UO}_{2}$ & - & 57.1 \\
\hline $\mathrm{Zr}$ & 21.2 & - \\
\hline $\mathrm{ZrO}_{2}$ & - & 28.7 \\
\hline $\mathrm{CrO}_{3}$ & 10.9 & - \\
\hline $\mathrm{Cr}$ & - & 5.7 \\
\hline Calcined Limestone-Common Sand Concrete & 8.5 & 8.5 \\
\hline
\end{tabular}

${ }^{*}$ Consists of 62.0 wt \% $\mathrm{Mg}_{2} \mathrm{Si}_{3} \mathrm{O}_{8}, 32.8$ wt \% CaO, and 5.2 wt \% $\mathrm{Al}_{2} \mathrm{O}_{3}$.

Table 2.4. Example of a thermite mixture designed to produce a fully oxidized core melt composition containing 8.5 wt \% LCS concrete. 
OECD/MCCI-2002-TR01 Rev. 2

\begin{tabular}{|c|c|c|}
\hline Constituent & $\begin{array}{c}\text { Reactant } \\
\text { (wt\%) }\end{array}$ & $\begin{array}{c}\text { Product } \\
\text { (wt\%) }\end{array}$ \\
\hline $\mathrm{U}_{3} \mathrm{O}_{8}$ & 59.4 & - \\
\hline $\mathrm{UO}_{2}$ & - & 57.1 \\
\hline $\mathrm{Zr}$ & 21.2 & - \\
\hline $\mathrm{ZrO}_{2}$ & - & 28.7 \\
\hline $\mathrm{CrO}_{3}$ & 10.9 & - \\
\hline $\mathrm{Cr}$ & - & 5.7 \\
\hline Calcined Siliceous Concrete $^{*}$ & 8.5 & 8.5 \\
\hline
\end{tabular}

${ }^{*}$ Consists of 79.1 wt $\% \mathrm{SiO}_{2}, 15.5$ wt \% $\mathrm{CaO}, 4.6$ wt $\% \mathrm{Al}_{2} \mathrm{O}_{3}$, and 0.8 wt \% MgO.

Table 2.5. Example of a thermite mixture designed to produce a fully oxidized core melt composition containing 8.5 wt \% siliceous concrete.

Molybdenum trioxide $\left(\mathrm{MoO}_{3}\right)$ has been used as the oxidizer in melt-spreading tests carried out for the purpose of characterizing corium viscosity [3]. In this case, Mo metal was produced as the reaction byproduct. Advantages of Mo are low vapor pressure, low solubility in the oxide phase, and large density in comparison to the oxide phase. Because of these properties, the Mo rapidly segregates and settles to the bottom of the melt layer. As a result, there is no extraneous metal present in the melt to influence crust morphology and hence the water ingression rate through the crust. Table 2.6 lists the pre- and post-reaction compositions for a chemical mixture that employs $\mathrm{MoO}_{3}$ as the oxidizer for production of a $50 \%$ oxidized PWR core oxide melt [3]. One potential disadvantage of this technique is that the Mo layer may not cleanly separate from the oxide during posttest disassembly, which could adversely affect the post-test crust strength measurement.

For tests in which structural steel is a desired melt constituent, a mixture of $\mathrm{Fe}_{2} \mathrm{O}_{3}$ and $\mathrm{CrO}_{3}$ can be utilized as the oxidizer for the reaction to yield molten stainless steel in the reaction byproducts. Table 2.7 shows the pre- and post-reaction compositions for a chemical mixture employing an oxidizer of this type to produce a 36\% oxidized PWR core oxide melt containing 18 wt \% structural steel $[3,4]$.

Finally, for tests in which a significant concrete content is desired in the reaction byproducts, concrete oxides can be added as metallic equivalents in the thermite mixture in such a way that they contribute to the heat of chemical reaction. An example of this type of thermite is shown in table 2.8, which provides the pre- and post-reaction compositions for a chemical mixture designed to produce a fully oxidized PWR core melt containing 20 wt \% calcined siliceous concrete [5].

The general procedure for development of a new thermite is summarized as follows. Reaction heat calculations are first performed to define a candidate mixture that will yield the specified melt composition at the target temperature. A small-scale (i.e., 200 g) reaction test is then carried out to measure the actual reaction temperature. If required, the chemical mixture is adjusted to achieve a higher or lower reaction temperature and the reaction test is repeated. Once this step is completed, additional tests are carried out at increased scale (i.e., $1 \mathrm{~kg}$ ) to assure that 
OECD/MCCI-2002-TR01 Rev. 2

\begin{tabular}{|c|c|c|c|}
\hline Constituent & Reactant & \multicolumn{2}{|c|}{ Product (wt\%) } \\
\cline { 3 - 4 } & (wt\%) & Before Mo Segregation & After Mo Segregation \\
\hline $\mathrm{U}$ & 48.45 & - & - \\
\hline $\mathrm{U}_{3} \mathrm{O}_{8}$ & 12.44 & - & - \\
\hline $\mathrm{UO}_{2}$ & - & 66.97 & 80.59 \\
\hline $\mathrm{Zr}$ & 13.73 & 6.86 & 8.26 \\
\hline $\mathrm{ZrO}_{2}$ & - & 9.27 & 11.15 \\
\hline $\mathrm{MoO}_{3}$ & 25.38 & - & - \\
\hline $\mathrm{Mo}$ & - & 16.90 & - \\
\hline
\end{tabular}

Table 2.6. Example of thermite mixture designed to produce a $50 \%$ oxidized PWR core melt composition with Mo metal as the reaction byproduct.

\begin{tabular}{|c|c|c|}
\hline Constituent & $\begin{array}{c}\text { Reactant } \\
(\mathrm{wt} \%)\end{array}$ & $\begin{array}{c}\text { Product } \\
(\mathrm{wt} \%)\end{array}$ \\
\hline $\mathrm{U}$ & 50.9 & - \\
\hline $\mathrm{UO}_{2}$ & - & 57.8 \\
\hline $\mathrm{Zr}$ & 21.5 & 13.6 \\
\hline $\mathrm{ZrO}_{2}$ & - & 10.5 \\
\hline $\mathrm{Fe}_{2} \mathrm{O}_{3}$ & 20.5 & - \\
\hline $\mathrm{Fe}$ & - & 14.4 \\
\hline $\mathrm{CrO}$ & 7.1 & - \\
\hline $\mathrm{Cr}$ & - & 3.7 \\
\hline
\end{tabular}

Table 2.7. Example of thermite mixture designed to produce a $36 \%$ oxidized PWR core melt composition containing 18 wt \% stainless steel.

\begin{tabular}{|c|c|c|}
\hline Constituent & $\begin{array}{c}\text { Reactant } \\
(\mathrm{wt} \%)\end{array}$ & $\begin{array}{c}\text { Product } \\
(\mathrm{wt} \%)\end{array}$ \\
\hline $\mathrm{U}_{3} \mathrm{O}_{8}$ & 52.54 & - \\
\hline $\mathrm{UO}_{2}$ & - & 50.56 \\
\hline $\mathrm{Zr}$ & 13.45 & - \\
\hline $\mathrm{ZrO}{ }_{2}$ & - & 18.18 \\
\hline $\mathrm{Si}$ & 6.34 & - \\
\hline $\mathrm{SiO}_{2}$ & - & 13.54 \\
\hline $\mathrm{CaO}$ & 4.50 & 4.50 \\
\hline $\mathrm{MgO}$ & 0.74 & 0.74 \\
\hline $\mathrm{Al}$ & 0.60 & - \\
\hline $\mathrm{Al}_{2} \mathrm{O}_{3}$ & - & 1.12 \\
\hline $\mathrm{CrO}_{3}$ & 21.83 & - \\
\hline $\mathrm{Cr}$ & - & 11.36 \\
\hline
\end{tabular}

Table 2.8. Example of thermite mixture designed to produce a fully oxidized PWR core melt composition containing 20 wt \% calcined siliceous concrete. 
the desired molten corium composition can be achieved and to characterize the resulting melt in terms of temperature, fluidity, and vapor pressure. Operational and safety characteristics are also investigated, including auto-ignition temperature, ignition characteristics, and stability under storage and handling conditions. These developmental tests are carried out in a separate experiment area (i.e., bldg. 206 walk-in hood) so that they do not hinder activities in the MCCI test area.

Operationally, the MCCI test area is currently equipped to handle a wide variety of thermite mixtures, except those requiring finely divided $U$ metal as an initial constituent. If water ingression tests with in-vessel conditions are specified (i.e., minimal concrete content), the $U$ metal must be incorporated to raise the reaction heat to the point where the reaction byproducts are molten. Due to the pyrophoric nature of finely divided U metal, these thermites are prepared in a glove box under an inert atmosphere. The chemical mixture must also be loaded into the test section and maintained under an inert atmosphere until the test is initiated. This is certainly within the scope of capabilities, but a glove box must be set up and certified for operation in the MCCI test area before water ingression tests can be prepared with such thermites.

\section{Crust Characterization}

\subsection{Debris Examination}

Following each quench test, the solidified corium will be removed from the test section for posttest examination and debris characterization. Before disassembly, the compression fittings under the lower flange will be removed and the thermocouples cut flush with the flange. This is done to ensure that the corium can later be pulled away from the lower flange and insulation. Also removed at this stage are all compression fittings and thermocouples penetrating the lower plenum sidewall. This is necessary to allow separation of the crucible from the surrounding pipe.

Disassembly begins by attaching I-beams with castors to the test section bottom flange. The Ibeams are then attached to the cell crane using chains. With the flange supported in this fashion the flange bolts can be loosened and removed. The crane is then used to lower the flange, which removes the upper plenum $\mathrm{MgO}$ liner and crucible with its contents from the RV. After setting this on the floor, the upper plenum liner and top section of the crucible are removed with the crane and set aside for the next test. This leaves the lower $30 \mathrm{~cm}$ sidewall of the crucible around the corium. A series of photographs will then be taken to document the appearance of the debris in this unaltered state.

After photographing the crust, the crane is attached to the remaining MgO sidewall liner. The liner is carefully lifted to separate it and the corium from the flange and its MgO insulation. The lower liner and its contents are then bagged and placed on a dolly for transport to the walk-in hood in Cell 6 for further examination and characterization. 


\subsection{Water Percolation Test}

The first posttest analysis will be a measurement of the water percolation rate through the crust. The corium remnants will be placed in a catch pan. The percolation rate is determined by rapidly pouring a known quantity of water on top of the crust and measuring the drainage time with a stopwatch. The drainage test will be carried out a second time to check for repeatability. Data from this test will be used to evaluate the crust permeability $\kappa$ from the following equation, which is derived from Darcy's law [6]:

$$
\kappa=\frac{\delta_{c}}{v_{l} g t_{d}} \ln \left(h_{0} / h(t)\right)
$$

for a crust thickness $\delta_{c}$, gravitational acceleration $g$, water drainage time $t_{d}$, liquid kinematic viscosity $v_{l}$, and initial water height $h_{0}$. The permeability estimate can be used to evaluate the dryout limit for comparison with that deduced from the quench rate data. For example, the following expression for the limiting heat flux in a porous medium can also be derived from Darcy's law:

$$
\mathrm{q}_{\mathrm{d}}^{\prime \prime}=\frac{0.5 \mathrm{~h}_{\mathrm{lv}} \kappa \rho_{1} \mathrm{~g}}{\mathrm{v}_{\mathrm{v}}}
$$

given the latent heat of vaporization $h_{l v}$, liquid density $\rho_{l}$, and steam kinematic viscosity $v_{v}$.

\subsection{Crust Strength and Chemical Composition}

The next step in the posttest analysis involves measurement of the mechanical strength of the crust. This will be performed with the apparatus shown in fig. 3.1. The overall objective of these tests is to provide basic information that is needed to validate the hypothesis that the crust will not be mechanically stable at plant scale. Therefore, to ensure scalability to plant conditions, it is critical to conduct the tests in a manner that produces the type of crust failure mode expected at full scale. In general, the failure mode for a flat plate under an applied load is a function of the aspect ratio, which is defined as the ratio of the plate diameter and thickness $(D / t)$. This aspect ratio would be $\sim 30$ for a postulated $20 \mathrm{~cm}$ thick crust formed by the water ingression mechanism within the typical 6 meter cavity span of most operating plants. For this case, finite element analysis of the plate mechanical response under a uniformly applied load indicates that the plate will fail under tension at the centerline [7] (included as appendix). This is therefore the target failure mode for the crust strength tests to ensure that the results are scalable to plant conditions.

Unfortunately, the crust thickness requirement for a proper strength measurement conflicts with the melt depth desired for dryout heat flux measurements. It is estimated that the minimum melt depth should be $8 \mathrm{~cm}$ to provide reasonable resolution of the dryout heat flux. (This assumes that there are no other factors at play during the quench process which could influence the quench rate, such as phase segregation.) This results in a $D / t$ of no more than four for the SSWICS RV geometry where the melt diameter is $30 \mathrm{~cm}$. Since an increase in the size of the reaction vessel to increase $D / t$ is not feasible, a more detailed analysis of the crust failure mode at 


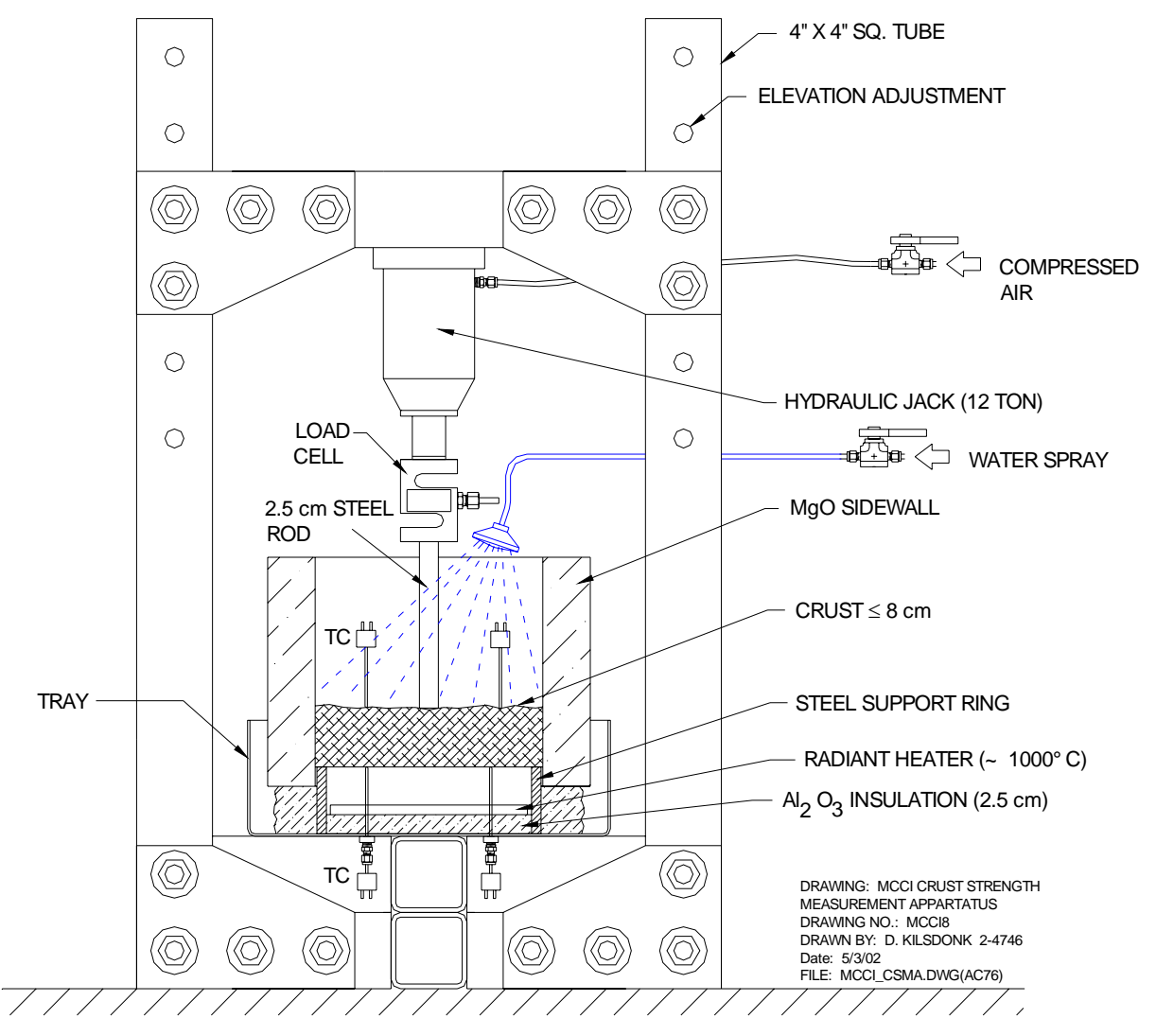

Figure 3.1 Crust strength measurement apparatus.

lower $D / t$ has been conducted to provide a technical basis for selecting the minimum $D / t$ that preserves the prototypic crust failure mode.

A series of parametric calculations were carried out using finite element structural analysis methods to examine the failure mode as a function of $\mathrm{D} / \mathrm{t}$ for brittle materials in which the ratio of the tensile to compressive strengths is $\sim 0.1$ (measurements conducted as part of the MACE program indicate that this is the case for corium). The results of these calculations indicate that the failure mode is accurately reproduced for aspect ratios greater than about four. For lower aspect ratios, the failure point shifts steadily outwards from the crust centerline towards the cavity wall. For small aspect ratios, $D / t \leq 2$, a non-prototypic plug-type failure mode is predicted. Thus, on the basis of these supporting structural analyses, the minimum aspect ratio is specified as four assuming that the crust behaves as an idealized flat plate with no pre-existing cracks. Since this is yet to be demonstrated in the load tests, the larger melt depth of $15 \mathrm{~cm}$ has been specified for the initial tests (see table 0.3).

If the load tests produce a non-protoypic plug failure mode, then two alternatives may be pursued in order to provide prototypic failure strength data: 
1. Conduct water ingression tests with $15 \mathrm{~cm}$ deep melts, and then section the specimens following the test to produce two $\sim 7.5 \mathrm{~cm}$ thick specimens that satisfy the criteria of D/t $\sim 4$. A preliminary check indicates that equipment exists at ANL to section these large specimens. However, it is important to note that the cutting process may affect the crack pattern within the corium that formed during the quench process. This would cast doubt on any strength measurements made with the sample after sectioning.

2. Conduct separate water ingression tests with shallower pools of nominally $8 \mathrm{~cm}$ thickness that can be directly tested in the loading apparatus. The dryout heat flux information would be compared with the $15 \mathrm{~cm}$ deep melts to check for repeatability.

Returning to the crust failure rig design, the objective of the measurement is to determine the crust strength through structural models that relate the load on a flat plate at failure to the plate yield strength, thickness, span, and a constant that depends on boundary condition (clamped vs. free), geometry (square vs. circular), and loading (uniform vs. concentrated). As shown in fig. 3.1, the test rig employs a concentrated load at the crust centerline and a support ring is provided beneath the crust so that a simply-supported boundary condition is achieved. A circular radiant heater is provided beneath the crust to heat its underside. The heater has a capacity of $1.8 \mathrm{~kW}$ (25 kW/m ${ }^{2}$ equivalent heat flux) and a maximum operating temperature of $1000^{\circ} \mathrm{C}$, which defines the maximum surface temperature to which the crust surface can be heated. A simple analysis indicates that $18 \mathrm{~kW} / \mathrm{m}^{2}$ would be needed to sustain a $1000^{\circ} \mathrm{C}$ gradient across an $8 \mathrm{~cm}$ thick crust $\left(\mathrm{k} \sim 1.5 \mathrm{~W} / \mathrm{m}^{\circ} \mathrm{C}\right)$. These figures indicate that the chosen heater has sufficient power to maintain a $1000^{\circ} \mathrm{C}$ temperature gradient. An additional requirement for the test will be water cooling of the upper side of the crust to maintain the gradient (natural convection losses to air would be insufficient to dissipate such a large input heat flux). A light water spray will be used to cool the crust via boiling. Thermocouples will monitor both the upper and lower surface temperatures of the crust during the load test.

As shown in figure 3.1, the load on the crust is gradually applied using an air-actuated hydraulic jack (50 kN capacity). The time-dependent applied load is measured with an in-line load cell (45 $\mathrm{kN}$ capacity) that is recorded on a data acquisition system. For a concentrated axial load at the center of a simply supported circular plate under the conditions in which $D / t \geq 4$, the maximum tensile stress develops at the centerline of the plate and is given through the following equation [8]:

$$
\sigma_{\max }=\frac{3 P}{2 \pi t^{2}}\left[(1+v) \ln \left(\frac{R}{r_{o}^{\prime}}\right)+1\right]
$$

Where: $\sigma_{\max }=$ maximum stress in plate, $\mathrm{P}=$ applied load, $\mathrm{t}=$ crust thickness, $\mathrm{D}=$ plate diameter, $v=$ Poisson's ratio ( 0.3), and $r_{o}{ }_{o}$ is the effective radius of the circular column that is in contact with, and applying the load to, the crust. This parameter is related to actual column radius and the crust thickness through the equation: 
OECD/MCCI-2002-TR01 Rev. 2

$$
r_{o}^{\prime}=\sqrt{1.6 r_{o}^{2}+t^{2}}-0.675 t \quad \text { for } \quad r_{o}<0.5 t
$$

Equation 3.3 has been compared with the maximum stress in the crust at failure predicted by the finite element analysis (see appendix). The comparison indicates that the closed form solution agrees with the detailed numerical analysis within $15 \%$ for an aspect ratio of $D / t=4$.

After the crust has been load tested using the above procedure, the debris will be collected and examined. Photographs will be taken of crust segments that provide good cross-sectional views of the crust axial phase distribution. At one documented location within the crust, small samples ( $\sim 1$ g) will be collected from the crust upper surface, lower surface, and the crust axial midplane. These samples will be submitted to the Analytical Chemistry Laboratory at Argonne for elemental identification by Inductively Coupled Plasma Atomic Emission Spectroscopy (ICP/AES), and phase characterization by X-Ray Diffraction (XRD). The data from these measurements will be used to determine the extent of axial phase segregation during the quench process.

\section{References}

[1] Ozisik M N, Heat Conduction, pg. 341, John Wiley \& Sons (1980).

[2] Jones S et al., Dryout Heat Fluxes in Particle Beds Heated Through the Base, Journal of Heat Transfer vol. 106 176-183 (1983).

[3] Farmer M T, Aeschlimann R W, and Spencer B W, "Estimates of Corium Viscosity for PWR and BWR Core Melt Compositions Based on Spreading Rate,” OECD Workshop on Ex-Vessel Debris Coolability, Karlsruhe, Germany, November 15-18 (1999).

[4] Binder J L, McUmber L M, and Spencer B W, Direct Containment Heating Integral Effects Tests at 1/40 Scale in Zion Nuclear Power Plant Geometry, NUREG/CR-6169, ANL-94/18, September (1994).

[5] Alsmeyer H, Farmer M T et al., The COMET-Concept for Cooling of Ex-Vessel Corium Melts, 6th Int. Conf. on Nucl. Eng., ICONE-6086, May 10-14 (1998).

[6] Dullien F A, Porous Media, Fluid Transport and Pore Structure, Academic Press, Inc. (1979).

[7] Pfeiffer P, Crust Structural Strength Measurement - Corium Melt Pool, Intra-Laboratory Memo to M. T. Farmer, Argonne National Laboratory, April 26 (2002).

[8] Young W C, Budynas R G, Roark's Formulas for Stress and Strain, $7^{\text {th }}$ Ed., TA 407.2 R628, (2002). 
ARGONNE

NATIONAL

LABORATORY

MEMO

INTRA-LABORATORY

April 26, 2002

To:

M. T. Farmer

RAE

From: $\quad$ P. A. Pfeiffer

RAE

Subject: $\quad$ Crust Structural Strength Measurement - Corium Melt Pool

References: [1] W. C. Young, R. G. Budynas, "Roark's Formulas for Stress and Strain," $7^{\text {th }}$ Ed., TA 407.2 R628, 2002.

[2] Private Communication, I. Therios to P. A. Pfeiffer, finite element results of plate analysis using ALGOR (commercial F.E.M. computer code), April 25, 2002

[3] Private Communication, M. T. Farmer to P. A. Pfeiffer, crust strength measurement concept and experimental setup, April 17, 2002

\section{Background}

This memo addresses the requirement of measuring the failure stress in the upcoming water ingression tests for the corium melt. The test will simulate a typical plant accident scenario in which a crust layer is formed. A typical plant has a cavity/pedestal diameter of approximately 6 meters. Factoring in other phenomena (eruptions, periodic failure events leading to crust ledges, etc.) the crust thickness may range up to $20 \mathrm{~cm}$ or so in an ex-vessel plant accident. This crust would have a hydrostatic water load on top of it, plus probably dead weight in the form of a distributed particle bed. Thus, the aspect (diameter width/thickness) ratio of this crust would be about $6 / 0.2$ or approximately 30 . As the accident progresses, the melt would tend to pull away from the bottom of the crust, leaving a situation in which the crust would be suspended in a cylindrical cavity with a simply supported boundary condition (no moment resistance capacity) around it's periphery under a fairly uniform applied load over it. The purpose of test is to address whether the crust would be structurally stable in this situation under the applied load, or would it mechanically fail, letting water through the crust and re-contact the melt beneath (i.e. "crust failure"). The purpose of the experiment, is to conduct on a small scale (relative to $6 \mathrm{~m} \mathrm{span}$ ), tests to provide strength data which could be scaled up for analysis of plant conditions. The current test stand is currently configured as a $30 \mathrm{~cm}$ ID test section in which it would generate a crust for the load testing. The test will consist of a platform in which a lance is used to provide a gradual load to the center of the crust. The lance would be affixed to a load cell, which will provide a load/time curve. The load force at crust failure would be measured. The intention is to use this test data and the appropriate formula, from Ref. [1] for a concentrated load on a plate, to evaluate the failure stress. This computed failure stress is used in a similar model (i.e. appropriate formula from Ref. [1] for uniform loading of a plate) to determine if the crust would be stable under prototypic plant conditions. 
$\underline{\text { Results and Recommendation }}$

The proposed formulas in Ref. [1] indicate these equations are valid under the assumptions of a minimum aspect ratio of $4(D / t=4, D$ : plate diameter, $t$ : plate thickness). Thus a ratio of $D / t>4$ would be valid for predicting failure stress and if less than 4 , the formulas would be inaccurate in predicting a failure.

A subsequent numerical analysis was done in Ref. [2], in which a finite element analysis of a simply supported plate with a central concentrated load was computed. This analysis was chosen to simulate the state of stress which would occur under the proposed testing program. Various ratios of $D / t$ were analyzed (1.5 through 30 ) and are given in Figure 1 . The results in Figure 1 are for a simply supported plate with a concentrated load of $1000 \mathrm{~N} / \mathrm{m}^{2}$ acting over a $1 \mathrm{~cm}$ radius at the center of the plate. The plate has outer radius of $30 \mathrm{~cm}$ with thicknesses of $1 \mathrm{~cm}, 2.5 \mathrm{~cm}, 5$ $\mathrm{cm}, 7.5 \mathrm{~cm}, 10 \mathrm{~cm}, 15 \mathrm{~cm}$ and $20 \mathrm{~cm}$ for the different analysis data points in Figure 1. The closed form formula from Ref. [1] was also depicted in Figure 1 for thicknesses ranging from $1.5 \mathrm{~cm}$ to $30 \mathrm{~cm}$. Additionally, an edge support stress, which is near the outer boundary of the plate (i.e. radius $=30 \mathrm{~cm}$ ), is plotted. The results indicate for $D / t=4$ and larger, the closed form solution and the finite element results agree very reasonably. However, as $D / t$ decreases from a value of 4 the results begin to differ considerably, see Figure 2 which is a magnified portion of Figure 1.

The results in Figure 2 also indicate at $D / t=3$ and smaller, the failure stress shifts from the center of the span (i.e at location of concentrated load) to the edge of the plate, due to the stress at the support being higher. Thus, the plate will fail in different mode, in which it fails at the edge rather than at its center location. In the typical plant failure discussed earlier, the type of failure will be at the center of the plate rather than at its outer radius (i.e. support location).

Thus, I would recommend a minimum $D / t$ of 4 for the test, because as $D / t$ becomes smaller the failure mode will change and the results will not be applicable to the typical plant accident scenario. The proposed loading scheme and setup with an elevated temperature, Ref. [3], is acceptable to use in the analysis of the typical plant accident scenario for determining a potential crust failure. Additionally, as indicated in Figure 2, if a value of $\mathrm{D} / \mathrm{t}<6$ is used for the test, the finite element results for the tension fiber stress at the center of the plate should be used rather than the closed form solution. The finite element results indicate the failure stress is approximately $15 \%$ lower for $D / t=4$, when compared to the closed form solution results. [Note: the closed form solution results in a conservative estimate of the failure stress for $D / t<6$, when compared to the finite element results. Thus the closed form solution may be used instead due to the upper bound stress solution.]

\section{PAP:pap}

cc: $\quad$ R. W. Aeschlimann

J. L. Binder

C. Grandy

D. J. Kilsdonk

S. Lomperski

D. Pan

Chron. 
OECD/MCCI-2002-TR01 Rev. 2

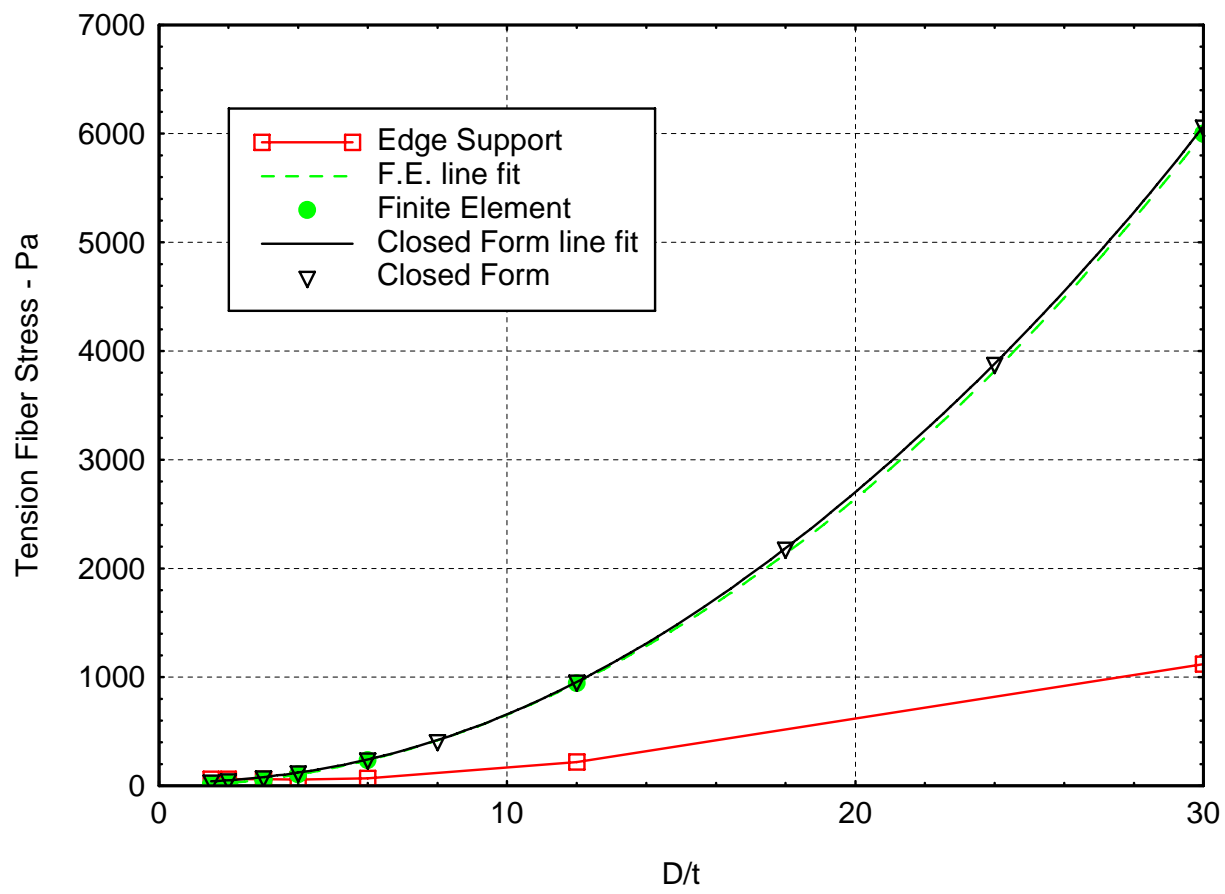

Figure A.1 Analysis Results for a Simply Supported Plate under a Center Load

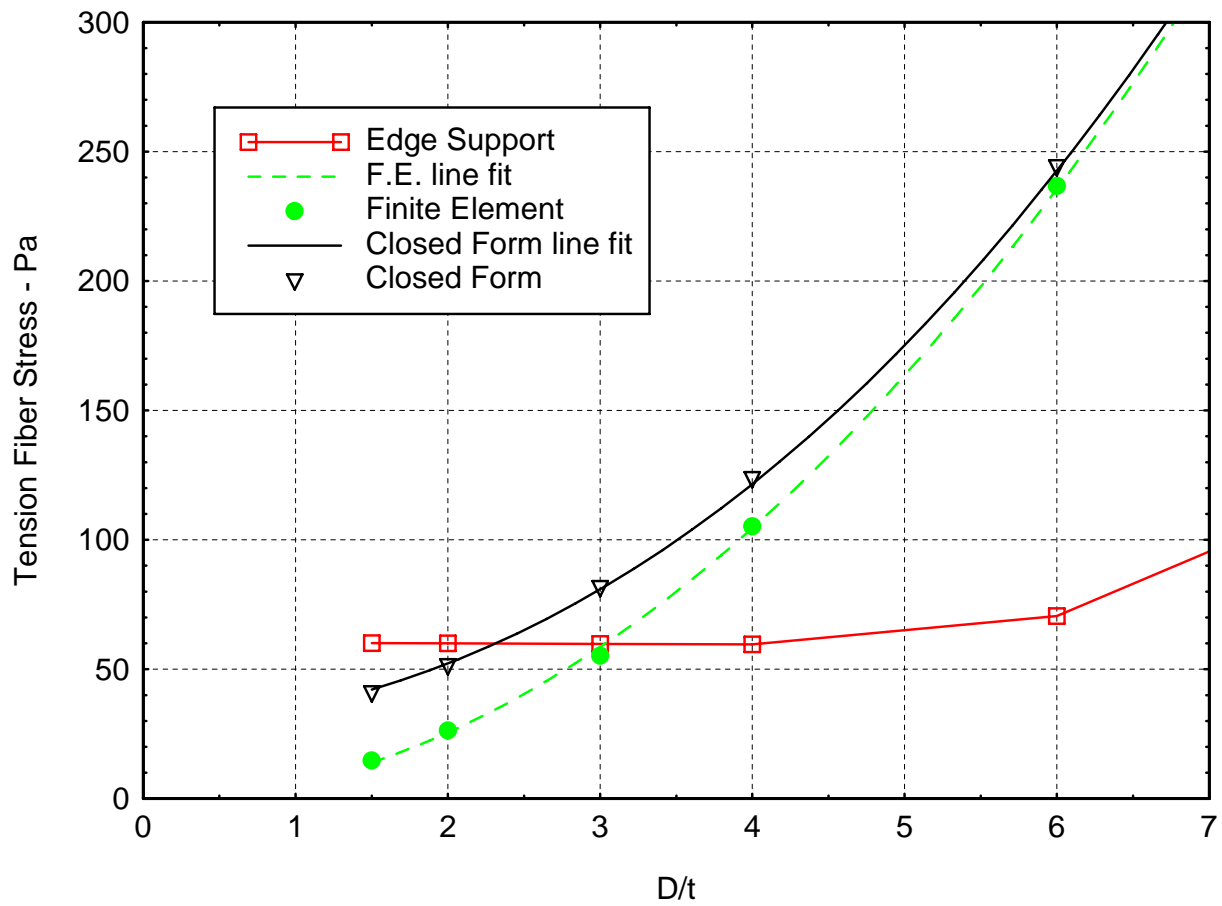

Figure A.2 Magnified Portion of Figure 1 to Indicate Analysis Differences 